University of Rhode Island

DigitalCommons@URI

Open Access Master's Theses

1981

\title{
THE PLANNING BOARD IN NEW HAMPSHIRE A HANDBOOK FOR LOCAL OFFICIALS
}

David R. Boutin

University of Rhode Island

Follow this and additional works at: https://digitalcommons.uri.edu/theses

\section{Recommended Citation}

Boutin, David R., "THE PLANNING BOARD IN NEW HAMPSHIRE A HANDBOOK FOR LOCAL OFFICIALS" (1981). Open Access Master's Theses. Paper 478.

https://digitalcommons.uri.edu/theses/478

This Thesis is brought to you for free and open access by DigitalCommons@URI. It has been accepted for inclusion in Open Access Master's Theses by an authorized administrator of DigitalCommons@URI. For more information, please contact digitalcommons-group@uri.edu. 
THE PLANNING BOARD

IN

NEW HAMPSHIRE

A HANDBOOK FOR LOCAL OFFICIALS

A Research Project Submitted In

Partial Fulfillment of The Requirements

For The Degree of Master of

Community Planning

David R. Boutin

Graduate Curriculum in

Community Planning and

Area Development

University of Rhode Island

May, 1981 


\section{MASTER OF COMMUNITY PLANN ING}

RESEARCH PROJECT

OF

DAVID R. BOUTIN

Approved :

Major Professor

Director

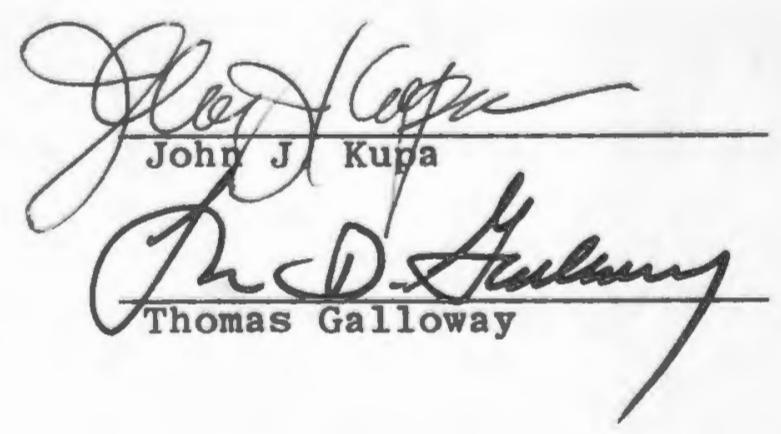




\section{ACKNOWLEDGEMENTS}

I would like to thank my academic advisor, Dr. John Kupa for his editorial comments and his general encouragement throughout the writing of this paper; David scott of the New Hampshire Office of state Planning, Donald R. Jutton, Town Manager of Salem, N.H., Jonathan Gilmore, Executive Director of the Southern Rockingham Regional Planning Commission located in Salem, N.H. and Jonathan Feinstein of wilbur Smith Associates for their editorial comments and general support.

I would also like to thank Mrs. Janet Frahm and Rose Marie Hartnett for their time and effort put into the typing of this paper.

And lastly, I would like to express my deep appreciation to my wife, Jan. She has shown her love and enduring support for me throughout the writing of this paper. Without her moral support this paper could not have been completed. 
TABLE OF CONTENTS

Page

LIST OF EXHIBITS AND APPENDICES

$\underline{\text { Preface }}$

Introduction

Chapter one: Questions About Community Planning

- What Is Community Planning

- How Does Planning Affect People

- Why Should A Community Be Involved In Community Planning

- What Is The Community Planning Process

9

9

10

11

Chapter Two: Municipal Planning Boards 13

- Grant of Power 13

- City Planning Boards 14

- Town Planning Boards 17

- Village District Planning Boards 20

- Statutory Provisions Applicable To All 22

Municipal

Planning Boards

Chapter Three: The Master Plan 29

- What Is A Master Plan 29

- Purposes of A Master Plan 29

- Preparation of Master Plan 31

- Adoption of Master Plan 34

- Legal Effect of Master Plan 36

Chapter Four: Zoning $\quad 39$

- Grant of Power 39

- Growth Management: Timing of Development 43

- Procedural Steps For Enactment of Zoning

- Official Map 49

Chapter Five: Subdivision And Site Plan Review 53

- What Is A Subdivision 53

- Minor Subdivision 53

- Grant of Subdivision Review Powers 54

- Adopting Subdivision Regulations 55

- Premature Subdivision 56

- Procedural Requirements of Subdivision 58

- Grant of site Plan Review Powers 62

Chapter Six: Summary of other Relevant statutes 65

Bibliography $\quad 70$ 


\section{LIST OF EXHIBITS AND APPENDICES}

\section{EXHIBITS}

1. N.H. Municipalities with Zoning Ordinances, 1980.

2. Illustration of items of concern in site Plan Review.

\section{$\underline{\text { APPENDICES }}$}

A. Reprint of New Hampshire's Planning Legislation.

B. Reprint of New Hampshire's zoning Legislation.

C. Model Planning Board By-Laws.

D. Organization of Zoning Ordinance

E. Procedure For Adoption of Zoning Ordinance:

Towns And Village Districts.

F. Criteria for Subdivision site Impact Analysis.

G. Organization of Subdivision Regulations.

H. Site Plan Review Checklist.

I. Glossary of Planning Terms. 
PREFACE

This handbook is an operating manual that outlines the powers, duties and responsibilities of the planning board as set forth in New Hampshire's Planning and Zoning Legislation. It is designed to be a handy reference for planning boards, and may also be of educational and practical value to Town and City Administrators; elected officials; other community Boards and Commissions; and to the layman citizen who has an interest in participating in the community planning process.

The population of New Hampshire grew by $20.2 \%$ during the 1970-1980 decade. It is expected to grow another $28 \%$ by 1990 , bringing the state's population to just over the one million mark. 1 New Hampshire's communities cannot shut out this growth, but must plan for it. This handbook will be helpful to planning boards, community leaders, and citizens in their understanding of New Hampshire's planning and zoning legislation; legislation which provides New Hampshire communities with the necessary tools for planning for orderly growth in the face of mounting pressures created by additional population growth.

The Introduction gives a historical overview of planning in the United states. Chapter one provides planning board members with some understandable non-technical answers for those often asked questions: What is Community Planning? How Does community Planning Affect People? Why Should our Community Be Involved In Community Planning? What Is The Community Planning Process? 
Chapter Two discusses how communities may establish a planning board. Chapter Three focuses on the planning board's principal statutory mandate - the formulation and implementation of a Master Plan. Chapter Four reviews the planning boards powers and duties and responsibilities as set forth in New Hampshire's Zoning legislation. Chapter Five addresses the planning board's subdivision and site plan review powers. Chapter Six summarizes other New Hampshire state laws which may be relevant to planning boards. 


\title{
INTRODUCTION
}

\begin{abstract}
"Londonderry is particularly interesting because it was a planned frontier community. Each house lot was laid on West Running Brook and comprised of about 60 acres. This method of planned community settlement became a starting point for several other towns such as Windham, Litchfield, Antrim, Peterborough and Acworth. " 2
\end{abstract}

\section{Planning In New Hampshire: A Historical Perspective}

The above quote indicates that community planning is not something new in New Hampshire. New Hampshire communities were laid out in a fashion similar to other New England towns. Early settlers during the mid-17th century designed their settlements to be self-contained rural-urban units with housing and commerce in the center of the settlement and farmlands in the outlying areas 3

Overview of The History of Planning In The United states

The idea of community planning can be traced back to the colonial days. William Penn in his layout for Philadelphia, Pennsylvania established a pattern of land development which influenced the design of many other colonial towns such as 
Washington, D.C., Savannah, Georgia and Cincinatti, ohio. 4

Three features of Penn's layout of Philadelphia were copied by many colonial towns which dominate the American landscape today. These features are: (1) gridiron street system; (2) system of open spaces; and (3) uniform spacing and setbacks for the buildings. 5 These are all common elements of today's modern day zoning plan.

Colonial town planning began to loose its importance in the early part of the eighteenth century. Economic growth became a more important consideration than orderly community growth.

Three factors have been identified as contributing to the decline of colonial town planning.

First, an anti-city bias developed. Thomas Jefferson's view of the city best captures the essence of the anti-city bias. He stated that the urban environment is: "pestilential to the morals, health, and liberties of man. 6

Secondly, intense economic competition among cities caused businessmen to be more concerned with developing railroads, canals and such other aspects of the city that would allow them to conduct business with outside areas rather than with improving the quality of life in the city. 7

And thirdly, the American Revolution gave rise to usurpation of many municipal powers by the state. As a result, communities lost much of their power to control the use of private property. The Revolution also encouraged land speculation, particularly in the West, but also in the urban centers of the Northeast.

Rapid advances in technology during the latter part of the eighteenth century created new job opportunities which lured 
large numbers of people off the farms and into the city. This centralization of population in urban areas resulted in problems such as street congestion, health hazards and the dangers of fire. The increased amplification of these problems as cities grew is what led to the revival of city and town planning.

A number of events took place in the late nineteenth and early twentieth century which further heightened the renewed interest in community planning. The two most notable events were the Columbian Exposition of 1893 which was organized by planners and architects and the city Beautiful Movement which began in 1901 and which is considered to be the basis of comprehensive planning as we know it today.

New York City's enactment of a zoning ordinance in 1916 which was the first of its kind in this country; publication of two model laws by the ${ }^{9}$ U.S. Department of Commerce, the standard Zoning Enabling Act in 1922 and the standard City Planning Enabling Act in $19288^{10}$ (many states have used those two model legislations as the basis for their planning and zoning statutes, including New Hampshire); and, a case decision by the U.S. Supreme Court that established the constitutionality of zoning (Village of Euclid, Ohio v. Ambler Realty Company, 272 U.S.363, 1926) were further stimuli to the revival of municipal planning in this country.

Planning and Zoning Legislation In New Hampshire

The New Hampshire legislature passed a comprehensive zoning 
act in 1925. It was not until 1935 that planning legislation was approved by the legislature.

Community Planning In New Hampshire

Community planning has been on-going in New Hampshire for some fifty years now. Earlier efforts to encourage community planning are attributable to the work of the New Hampshire Office of state Planning and the Regional Planning Commissions. The "701" program, a Federal grant program, provided much of the seed money for the preparation of Master Plans in many of New Hampshire's communities.

The Forum on New Hampshire's Future which was formed in 1977 has continued the earlier efforts of the state Planning office and the Regional Planning Commissions. The Forum's mandate was to teach New Hampshire residents of the need for and benefits of community planning.

Data from the office of state Planning indicates that 175 communities have formed planning boards and enacted zoning ordinances (see exhibit 1); and according to a survey conducted in 1980 by the Forum, 91 of the 234 cities and towns have existing master plans, and 100 communities are either updating or developing a master plan. 11

In January of 1981, the Forum on New Hampshire's Future was succeeded by the Center for New Hampshire's Future (a collaboration of the University of New Hampshire, Dartmouth College, government and private citizens). The Center provides New Hampshire communities with technical assistance on community planning issues. 
FOOTNOTES FOR PREFACE AND INTRODUCTION

1. Frank P. Bril1, "NH Economy Best In Frostbelt States", Manchester Union Leader, 2 February 1981, p.1.

2. J. Duanne Squires, The Story of New Hampshire (Princeton, New Jersey: D. Van Nostrand Company, Inc., $1964), \mathrm{p} .16$.

3. William I. Goodman and Eric C. Freund, Principles and Practice of Urban Planning (Washington, D.C.: International City Managers' Association, 1968, p. 12.

4. Ibid., pp. 8-11.

5. Ibid., p. 9 .

6. Ibid., p. 12 .

7. Ibid., p. 13

8. Ibid., p. 20 .

9. Ibid., p. 24.

10. Ibid., p. 23-24.

11. Gail Kelley, "Three Years Progress In Growth Management", Forum News On New Hampshires Future, vol.2, January 1981, p.1. 
CHAPTER ONE: QUESTIONS ABOUT COMMUNITY PLANNING "Planning, in the broadest sense, is a process of identifying ways to make the best use of resources $\$ \circ$ as to surmount problems and meet
goals."

What Is Community Planning? It is a process of identifying community resources and determining ways to best allocate those resources. Community resources include: land with consideration for its physical limitations; existing physical plant such as municipal buildings, senior center, parks, sewer and water systems and other such facilities; existing physical development including agricultural, residential, commercial and industrial land uses; Planning is for people; it is a democratic process by which residents of a community collectively decide on the future growth and development of their community.

Planning is a continuing process. It enables communities to anticipate change and to respond to it with appropriate municipal action.

How Does Planning Affect People? Planning affects people in many positive ways. Some examples of how good planning can bring positive benefits are: (1) tax dollars are saved when well-informed decisions are made; (2) property values are protected by insuring that adequate buffer zones exist between residential and commercial and industrial properties; (3) continued maintenance of the roads and sidewalks in the business district encourages residents to patronize those shops rather than going to regional shopping 
centers. The list could go on and on, but the above examples of positive benefits derived from good planning make it clear that planning can enhance the overall "quality of Life" in a community.

Why should A Community Be Involved In Community Planning?

A community should be involved in an on-going community planning program because local government (versus state or Federal) is the only body with an opportunity to successfully coordinate the over-all physical development of the community. Planning for the community's physical development not only makes good sense, it makes good business sense.

Communities should also be involved with community planning for the purpose of protecting and enhancing the "quality of life" for its residents. It is the "quality of life" factor which has and will continue to attract large numbers of people to New Hampshire for recreation and for permanent residence. A community that has identified its resources and how to best utilize those resources will be in a better position to promote and enhance the community's "quality of life".

The following is an incomplete list of other reasons why communities should establish a community planning program:

1. To promote opportunities for persons of diverse backgrounds to live in safe, healthful, comfortable and appealing dwellings;

2. To minimize danger to life, health, and property resulting from fire, flooding, pollution or other potential dangers.

3. To enhance and preserve the beauty and character of the community; 
4. To protect and encourage the continuation of farming;

5. To encourage the efficient use of land;

6. To encourage employers to remain, expand, or locate within the community;

7. To sustain and attract commercial services which will serve the convenience and needs of the residents;

8. To maintain and improve the safety of the roads;

9. To protect fragile environments;

10. To promote energy conservation practices;

11. To maintain and enhance recreational opportunities; and

12. To maintain and enhance the quality of municipal services provided at an efficient cost.

There may be other reasons why a community would want to be involved in a community planning program. Once a community has decided that community planning makes sense, more specific reasons for undertaking a community planning program may be identified through a community planning process.

What Is The Community Planning Process? The process involves an identification of a community's assets and liabilities. A community in the development of its Master Plan would analyze this information and then decide how best to maintain and enhance its assets and overcome its liabilities.

The first step a community must take before starting a community planning program, if it hasn't already done so, is to form a planning board. How to form a planning board is the subject of Chapter Two. 
FOOTNOTES FOR CHAPTER ONE

12. Mark stein, Teaching Planning To Connecticut Townspeople (Storrs, Connecticut; Institute of Public service, University of Connecticut, 1977), p. 41.

13. Ibid., pp. 46-47. 
CHAPTER TWO: MUNICIPAL PLANNING BOARDS

"The planning board is an advisory body which serves as a liasion between the governing body and the electorate in connection with the ${ }_{1}$ omprehensive development of the community." 14

New Hampsire's Planning legislation is contained in Chapter 36 of the Revised statutes Annotated (1955), and is entitled Planning Boards (see Appendix A for a complete reprint of the Planning legislation). This stature empowers municipalities to create by ordinance a planning board, and to delegate to that board the powers and duties which are described in chapter 36 . Municipalities cannot exercise their state delegated police powers to guide and control community development without first creating a planning board.

Chapter 36 contains several sub-titles: Municipal Planning Boards, one of the several sub-titles contained in Chapter 36, is the subject of this chapter.

MUNICIPAL PLANNING BOARDS

\section{Grant of Power}

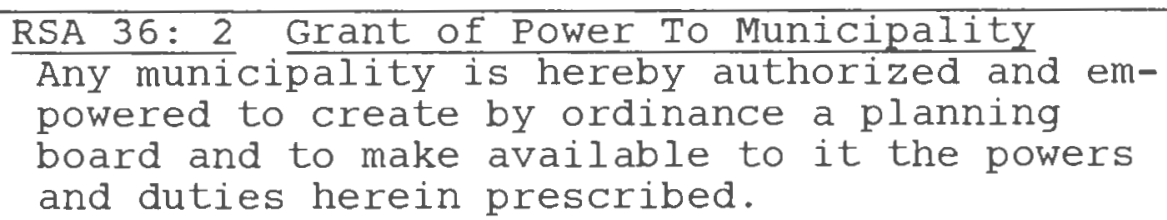

The legislative body of the community is empowered to adopt an ordinance creating a planning board; the city council in the case of towns and village districts. 
The key phrase contained in RSA 36:2 is "create by ordinance". A council resolution or town or village district meeting article by itself will not satisfy the legal requirements of RSA 36:2. The ordinance creating the planning board should make specific reference to the powers and duties of the planning board as set forth in Chapter 36.

Designation of Planning Board

RSA 36:3 Designation of Planning Boards. The planning board of any city shall be designated city planning board; of a town or village district, town or village district planning board; and of a region, regional planning board.

Section 3 simply refers to the name designation of municipal planning boards.

Membership On Municipal Planning Boards. There are some variations in the planning legislation pertaining to the number and terms of members of city, town and village district planning boards. As such, it was felt that the reading would be made easier if each type of municipal planning board was discussed under a separate heading.

\section{CITY PLANNING BOARDS}

Membership

The legislative body in the city form of government is either the City Council or the Mayor and the Board Alderman (for uniformity the term city council will be used when making reference to the legislative body of cities). The city council may adopt an ordinance creating a city planning board subject to the public hearing requirements of RSA 47:26. 


\begin{abstract}
RSA 36:4-I. In the case of cities, the planning board shall consist of nine members, namely, the mayor, one of the administrative officials of the municipality who shall be selected by the mayor, an a member of council who shall be selected by it, as members ex officio, and six persons who shall be appointed by the mayor, if the mayor be an elective office, otherwise by such officer as the council may in the ordinance creating the planning board designate as the appointing power.
\end{abstract}

City planning boards must be comprised of nine members. Three of the members are city officials: the mayor, an administrative official selected by the mayor, and a city councilor chosen by the city council. These three people are ex officio members with full voting privileges. The remaining six members are citizens who are appointed by the mayor, or in the case where the mayor is not an elective officer, by such other officer as the city council, in the ordinance creating the planning board, designates as the appointing power.

Terms of Members

RSA 36:5-II provides that the length of term for the ex officio members shall correspond to their elected term of office. The administrative official is not an elected officer, but his position on the planning board terminates with ther term of the mayor selecting him.

The respective terms of the first five appointed citizen members are for one, two, three, four, and five years. The statute does not specify the length of term for the sixth member. However, it does offer some guidance in that the statute requires that all subsequent appointments be for six years. Therefore, it would 
probably not be inconsistent with the statute to appoint that first sixth member for a six year term.

At the end of a member's term, he may be re-appointed for a six year term (RSA 36:5-II). If the council chooses not to reappoint that member, or that member declines re-appointment, then another citizen would be appointed to the planning board for a six year term.

The general purpose of staggered terms, which also applies to town and village district planning boards, is to insure a continuing participation of experienced members on the planning board. It also promotes continuity in the community planning process. Holding Other Municipal office

City planning board members are, in general, prohibited from holding any other municipal office. The statute, however, does provide for three exceptions as outlined in RSA 36:5-I.

RSA 36:5-I (a) One of such appointed member may be a member of the zoning board of adjustment: (b) Either one appointed or one ex officio member may be a member of the conservation commission, if one exist in the city, in accordance with RSA 36-A:3;

(c) Either one appointed or one ex officio member may be a member of the historic district commission, if one exist in the city, in accordance with RSA 31:89-d.

Filling of Vacancies

A vacancy that may occur on a city planning board for reasons other than an expired term is to be filled in accordance with the provisions of RSA $36: 7$. 
RSA 36:7-I. By the mayor for members selected or appointed by him;

II. By the city council in the case of a city councilor member; and

III. By the appointing power which has been

designated by the council in municipalities in

which the mayor is not an elective officer.

\section{TOWN PLANNING BOARDS}

The annual town meeting is the legislative body in the town

form of government. An ordinance to create a town planning board must be adopted by the annual town meeting. It is important to reiterate that that ordinance should specifically delineate the planning board's powers and duties as set forth in chapter 36. Membership

Towns, at the option of town meeting, may elect to have either a five member or a seven member planning board; and towns, at the option of town meeting, may choose to delegate the power of appointing planning board members to the selectmen, or to have the townspeople elect persons to the planning board.

RSA 36:4-II. In the case of towns, the planning board shall consist of either five or seven members, at the option of the town meeting, and the membership may be filled as provided in subparagraphs (a) or (b).

(a) The selectmen of the town may choose one selectman to act as an ex officio member, and appoint four or six other persons, depending upon whether the entire planning board includes five or seven members respectively.

(b) The town, by majority vote at the town meeting, may decide to elect the members of the planning board. If such a procedure is adopted at the town meeting, the planning board members shall be elected at the next regular town meeting as provided for in RSA 669:17. 
Terms of Members

The initial length of terms for members of town planning boards are: in the case of a seven member board for one, two, three, four and five years; and, in the case of a five member board for one, two, three and four years.

The statute again does not specify the length of term for the sixth member of a seven member board. However, it again offers some guidance in that the statute requires that all subsequent appointments be five years in the case of a seven member board. Therefore, it would probably not be inconsistent with the statute to appoint the sixth member of a seven member board to a five year term.

The selectman's term corresponds to his elected term of office.

Holding other Municipal office

Members of town planning boards are not restricted from participating on other town boards or commissions (RSA 36:5-I). However, not more than one planning board member may serve on the same board or commission. Participation on other town boards and commissions is a good practice. Planning board members can Iearn what community planning related concerns other boards and commissions might have; and likewise, planning board members can use the opportunity to explain the basis for their current community planning activities. It is also an opportunity to discuss what they see as community planning issues which the community must eventually address. 


\section{Filling of Vacancies in Membership}

A vacancy in the membership of a town planning board occurring otherwise than through the expiration of a term is filled by the selectmen (RSA 37:7-IV). This holds true regardless of whether the vacancy is for an appointed or an elected position on the planning board.

Readers should be aware that two sub-sections of Chapter 36, 36:4-II(b) (I) and 36:4-II(b) (2), were inadvertently repealed from the planning enabling statute during the 1979 legislative session. Those two sub-sections had to do with terms of elected planning board members.

RSA 36:4-IIb) (1). For a five member planning board, the town shall initially elect two members for a one year term, one member for a two year term, and one member for a three year term. The fifth member shall be a selectman appointed by the selectmen, ex officio, whose term shall correspond to his official tenure. Thereafter the term of an elected planning board member shall be three years.

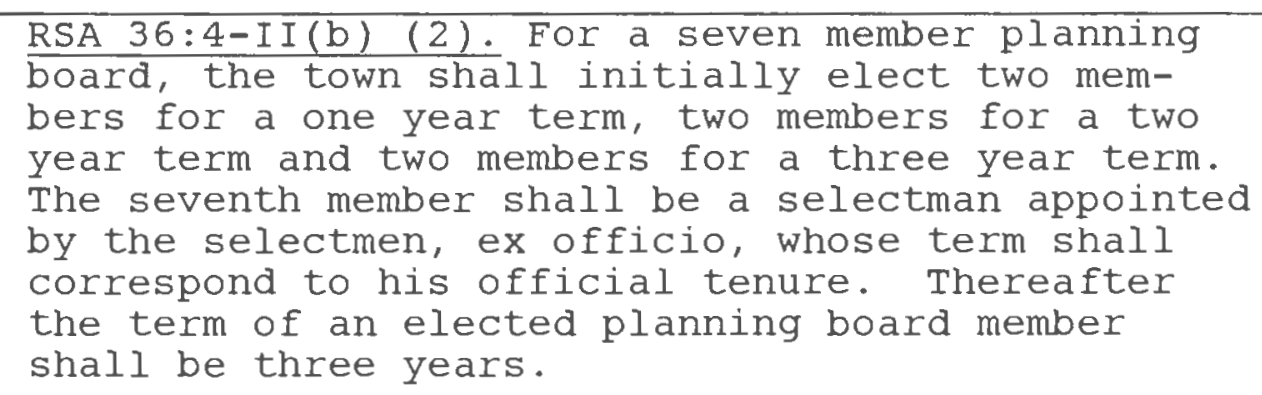

The ommission of the above two sub-sections creates some confusion for towns that decide to elect their planning board members. This matter should be corrected during the 1981 legislative 
session as a bill has been submitted to re-insert in the statute those two sub-sections.

The provisions of RSA 36:4-II(b) (3) were deleted from Chapter 36 as a result of a recodification of Town Election Laws into a new Chapter (Chapter 669:17) during the 1979 legislative session.

RSA 36:4-II(b) (3). If a town with an appointed planning board votes to elect the planning board, the terms of office of the existing members of such board shall expire when the first election of planning board members is held.

RSA 669:19 provides for a uniform manner of electing town officers, including planning board members. Planning board members may be elected by ballot or by other means (not specified) at the time of the annual town elections or annual town meeting, whichever is determined by the townspeople.

Planning board members may be elected to office at the next meeting or election succeeding the one at which the townspeople voted to establish an elected planning board.

If there already exists an appointed planning board and the townspeople vote to change to an elected board, the appointed members remain in office until the next annual town election or annual town meeting.

\section{VILLAGE DISTRICT PLANNING BOARD}

The annual village district meeting serves as the legislative function in the village district form of government. An ordinance to create a village district planning board would therefore have to be adopted at the annual village district meeting. Again, it 
needs to be stressed that that ordinance be specific as to the powers and duties that are being delegated to the village district planning board.

Membership

RSA 36:4-III allows village districts, at the option of the village district meeting, the choice of having either a five or seven member planning board. Four or six members, depending on the size of the planning board chosen by the village district meeting, are appointed by the district commissioners. Village districts do not have the option of electing their planning board. The district commissioners must appoint one commissioner to serve on the planning board. The appointed commissioner serves as an ex officio member with full voting privileges.

\section{Terms Of Members}

The terms of appointment and reappointment for members of village district planning boards are the same as for town planning board members as was discussed in the foregoing section of this chapter.

Holding Other Municipal Office

The statue does not address this matter at all as it does for city and town planning boards. It would seem practical to apply the same guidelines to village district planning boards that apply to town planning boards, that not more than one member of a village district planning board serve on any other village district board or commission. Before making such a provision a part of an ordinance to create a village district planning board, the district commissioners should seek legal counsel on the matter. 


\section{Filling of Vacancies In Membership}

A vacancy in the membership of a village district planning board is filled by the appointment of another person by the district commissioners.

\section{STATUTORY PROVISIONS APPLICABLE TO ALL}

\section{MUNICIPAL PLANNING BOARDS}

\section{Remova1 Of Members}

RSA 36:6 Removal Of Members of Planning Board Members of a planning board other than members selected by council may, after public hearing, be removed by the mayor for inefificiency, neglect of duty, or malfeasance in office. Council, selectmen, or district commissioners may for like cause remove the members selected by them. Selectmen may for like cause remove an elected member. The mayor or the council, selectmen, or district commissioners, as the case may be, shall file with the city or town clerk, or clerk of the board of district commissioners whichever is appropriate, a written statement of reasons for such removal.

Persons who accept an appointment to a planning board must keep in mind that they are assuming a position of public trust; and those persons have a responsibility to uphold that public 
trust. Members who fail to uphold the public trust because of inefficiency, neglect of duty, or malfeasance in office may, after a public hearing, be removed from the planning board. A written statement of the reasons for dismissal of a planning board member must be submitted to the city, town or village district clerk whichever is appropriate.

\section{Planning Board Alternates}

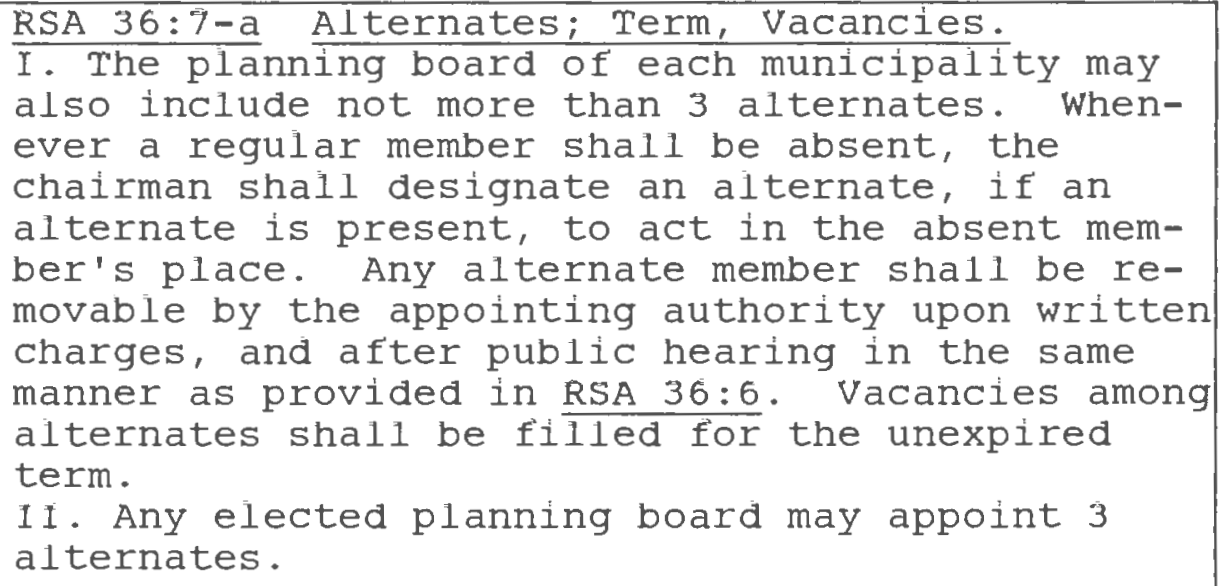

without a quorum at a public hearing a planning board cannot proceed with any official action. If this situation were to occur, it would create a hardship for planning board members present; it would be an even greater hardship to the applicants who had expected their case to be heard that evening. Communities can and should act to avoid an occurrence of this sort by appointing at least one or two alternates, if not three which is the maximum allowable number of alternates as provided for in RSA 36:7-a.

Planning board alternates on those occasions when they are asked to be present should use good discretion when and if they vote for the approval or disapproval of a plan. If the alternate 
is not totally familiar with the plan, he should abstain from voting. If an alternate is sitting on the board on an evening when preliminary plans come before the board for the first time, it is probably advisable for the chairman to have that alternate rather than the regular member sit in review of the plan when it comes up for review as a final plan.

Planning boards should consider including a section in their by-laws that establishes the organizational role and function of planning board alternates.

Having planning board alternates is a reasonable assurance that the planning board will always be at full strength with its designated number of members. Additionally having planning board alternates creates a readily available pool of persons who are knowledgeable of the workings of the board.

Organization, Meetings And Rules

RSA 36:8 Organization, Meetings and Rules. The planning board shall elect its chairman from the appointed or elected members and create and fill such other offices as it may deem necessary for its work. The term of the chairman shall be one year, with eligibility for re-election. The planning board of a city shall hold at least one regular meeting in each month and the planning board of a town or village district shall hold at least one regular meeting every 3 months; provided however, a town planning board shall meet at least ninety days before the town meeting date to accept petitions for zoning and building code changes. Following receipt of the petitions for zoning and building code changes, at least 90 days before town meeting, the planning board shall post the first hearing immediately, and subsequent hearing pursuant to the procedure as specified in RSA 31:63-a. The planning board shall adopt rules for the transaction of business and shall keep a public record of its resolutions, transactions, findings, and determinations. 
The planning board elects its own officers. These officers normally will include a chairman, elected annually who will conduct meetings and be the official spokesman for the board; a vicechairman to act in the absence of the chairman; and a secretary who will keep records, see that proper notice is given, and take care of other administrative detail.

The planning board should officially adopt by-laws to govern its internal organization and its business with the public. The policies, rules and procedures contained in the planning board's by-laws must be in accordance with the provisions of Chapter 36 , and all other New Hampshire statutes which relate to the affairs of municipal planning boards. A model copy of suggested planning board by-laws developed by the southern New Hampshire Regional Planning Commission is included in Appendix $\mathrm{C}$.

Many times planning boards get themselves into difficult situations because of a lack of attention to administrative detail. While planning boards should be careful not to overload themselves with administrative detail, they should be equaliy careful that they do not permit themselves to operate carelessly.

\section{$\underline{\text { staff And Finances }}$}

RSA 36:9 Staf'f And Finances. The planning board may appoint such employees as it may deem necessary for its work, whose appointment, promotion, demotion and removal shall be subject to the same provisions of $l a w$ as govern other corresponding civil employees of the municipality. The planning board may also contract with city planners, engineers, architects, and other consultants for such services as it may require. The expenditures of the planning board, exclusive of gifts, shall 


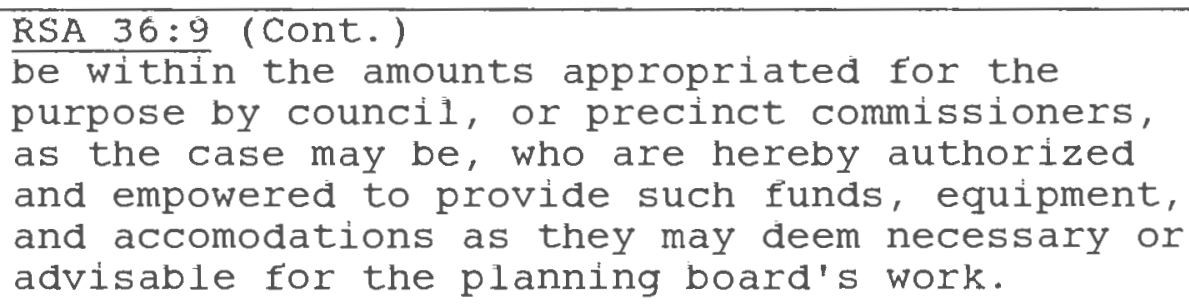

The planning board may hire professional consultants as funds permit, but the planning board should recognize that no professional can solve all the problems alone. The planning board must work very closely with the consultant to insure that the needs and desires of the townspeople are fully considered. The implementation of project recommendations will ultimately be the responsibility of the planning board, not the professional consultant.

\section{Miscel1aneous Powers And Duties}

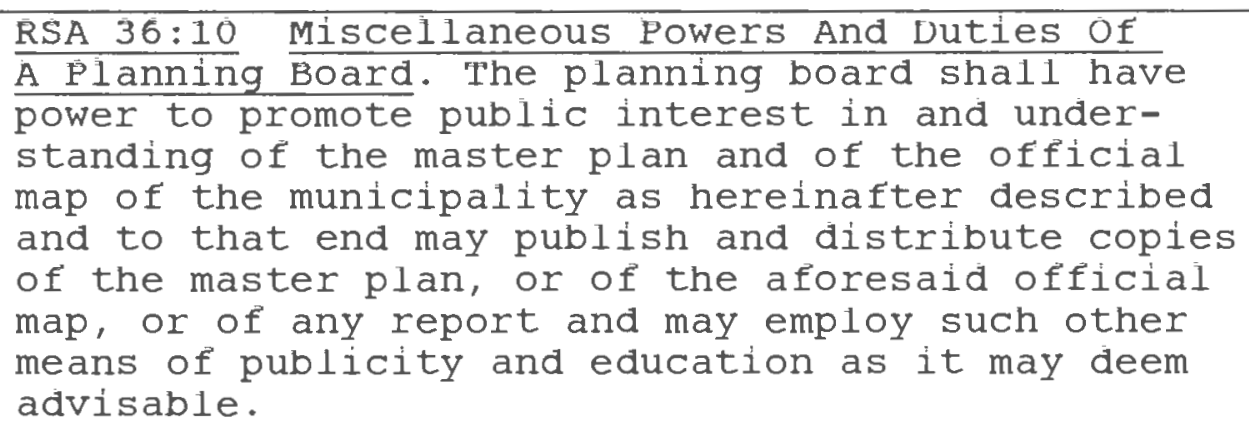

The success of a community planning program is greatly dependent on the nature of the planning board's community relations. The presentation of plans, the communication of planning ideas, the education of people concerned with specific problems - all these are aspects of the relations of the local planning board with the public. Planning boards can fulfill their responsibility to keep the public informed of on-going planning activities and 
enhance community relations through mediums such as publications, news releases, public hearings, and special workshops.

The planning board, when initiating a planning program, must be prepared to deal with other public agencies. The formulation of a coordinated planning program cuts across the areas of responsibility of the city council, selectmen, or village district commissioners, the school board, the housing authority, the conservation commission, the historic district, the board of adjustment, other community boards and commissions, and municipal departments. In some cases, private organizations such as the chamber of commerce and other similar civic groups are very much involved in activities that affect the development of the community. Planning boards should understand that these other agencies and groups tend to deal with specialized functions or activities, and are not likely to be aware of, or understand the issues and problems related to planning for the overali development of the community. To work successfully with these agencies and groups, the planning board must learn to tactfully assume both an educating and coordinating role without creating a feeling of interference.

This chapter has emphasized the statutory provisions of the planning enabling statute pertaining to the creation of a municipal planning board. The next chapter, The Master Plan, focuses on another sub-title of the planning enabling statute, Master Plan of The Municipality. 
FOOTNOTES FOR CHAPTER TWO

14. Herbert $H$. Smith, The Citizen's Guide To Planning (West Trenton, New Jersey: chandler-Davis Publishing Company, $1961), \mathrm{p} .14$. 
"If our communities are not to be bankrupted by wasteful and uncoordinated development, we must have practical plans for the future; if we are not to be overwhelmed by man-made ugliness, we must see to it that our plans

The general function of a planning board is to prepare a master plan, and to investigate, advise and recommend with respect to municipal planning matters on a continual basis.

What is A Master Pian?

The master plan is a document or series of documents that contain comprehensive surveys and studies of existing community conditions, data and information relative to the probable future development of the community. It sets forth policies and recommendations concerning all aspects of community growth and development. It is a reference document that offers guidelines for community decision-makers. A master plan assists a community in guiding change and managing growth in an orderly and constructive manner by presenting coordinated policies for housing, commercial and industrial development, transportation, environmental protection, community facilities, and sound fiscal management.

Purposes of A Master Plan

RSA 36:13 sets forth the purposes of the master plan and charges the planning board with the responsibility of preparing and implementing the master plan. 
RSA 36:13 Purposes of Master Plan. It shall be the function and duty of any planning board established under the provisions of this chapter, to make and to perfect from time to time, so far as funds appropriated by council for such purposes will permit, a master plan for the development of the municipality, including any areas outside of its boundaries which, in the plamning board's judgement bear relation to the planning of the municipality.

The master plan should include such maps, charts and descriptive matter which will adequately represent the planning board's recommendation. Some of the key elements of a master plan include: land use plan, traffic circulation plan, recreation plan, public facilities plan and zoning plan.

There are several reasons why communities are motivated to prepare a master plan. Some communities do it in response to growth pressures and in recognition of the need to plan for the community's future development while other communities do it in the belief that planning can slow development. While it is true that good planning can result in more orderly growth, it should never be used to attempt to build a fence around the community. A community should pursue the development of a master plan for the several reasons listed below.

1. To provide policy direction for municipal officials in their day-to-day decision making; and to provide policy direction for developers, business and residents of the community.

2. To priortize community needs and to determine alternative means for meeting those needs, over time, in a fiscally responsible manner. 
3. To establish a planning data base, including an inventory of community resources which can be periodically updated to reflect changing trends which, in turn, may warrant a re-thinking of community development policies.

4. To establish a legal basis for growth management regulations.

\section{Preparation of The Master Plan}

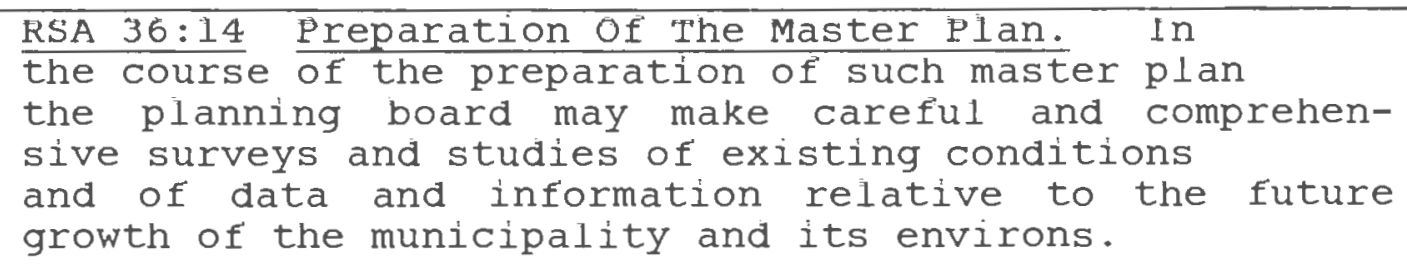

The preparation of a master plan consist of proceeding through a series of related steps that assemble community information and formulate development recommendations based on public desires and physical/legal/fiscal constraints. A suggested series of steps to follow are summarized below.

1. Establish community goals: find out what residents think about their community, and what they want it to be like in the future.

- conduct a public opinion survey

- citizen participation through a citizen advisory committee.

- discuss community growth and development issues with residents, municipal officials, and other community boards and commissions.

- conduct a public hearing to share the results of the opinion survey with residents.

- prepare and distribute issue papers which discuss various aspects of community development i.e. population growth, public services, housing, or the viability of the local economic base.

2. Inventory and analysis of existing conditions: identify problems and potentials.

- population and economic data, growth trends and projections for the community and the region. 


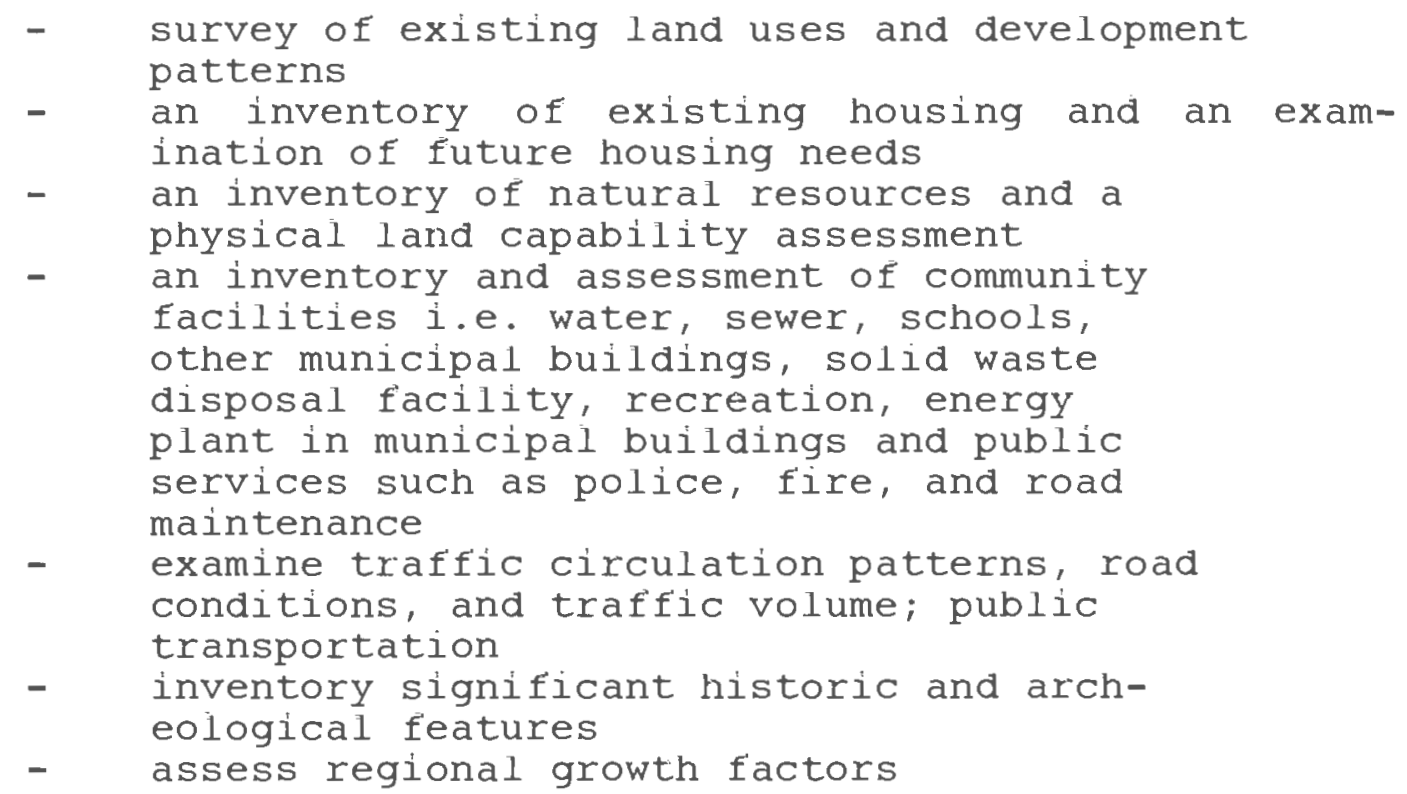

3. Prepare a community growth policies plan.

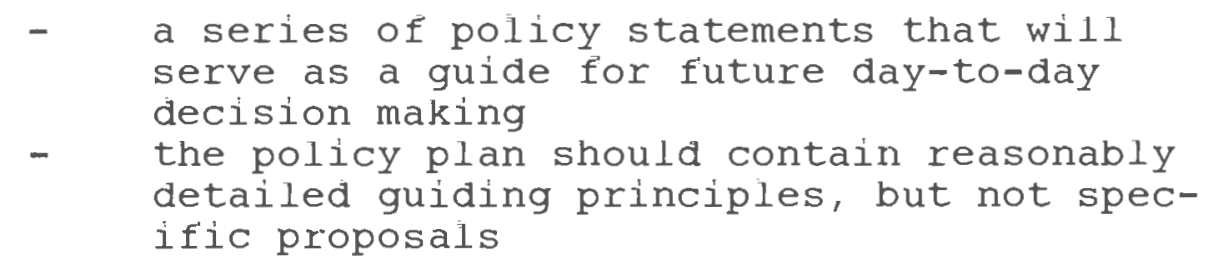

4. Prepare future land use plan: take into consideration community goals and policies while respecting legal guidelines.

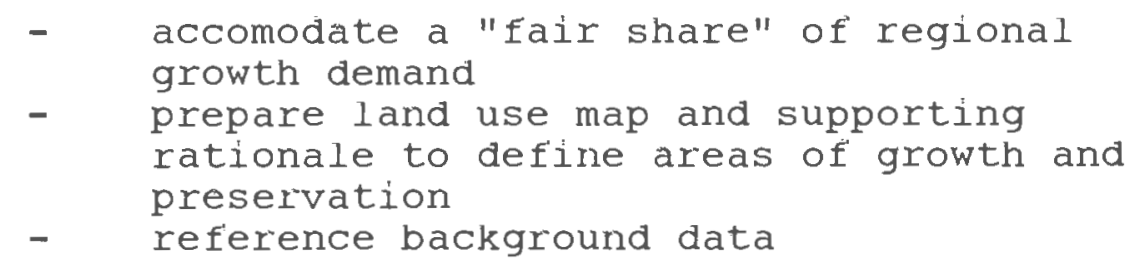

5. Prepare a summary describing alternative techniques for implementing the recommendations.

- the basic techniques include: zoning ordinance and map; subdivision and site plan regulations; building codes; capital improvements program; land acquisition and easements; and timed development strategies that are based on the availability of community services such as sewer and water

- identify the estimated costs of implementing each of the plan recommendations and how the money will be raised; whether it will be Federal, state, or local funds 
6. Establish a procedure and time schedule for review of the master plan to assess its validity in light of existing circumstances at that time.

- planning board establish an annual session for the re-evaluation of the planning goals and program

- assess the success or failure of implementing the plan recommendations; assess current community issues; and, if necessary, amend the master plan to address changing community conditions

The text of the master plan should contain at least three major sections: Introduction which should describe what a master plan is, why the community needs it, and how it is to be used and implemented; Background Information which should contain a summary and evaluation of findings made during the community inventory phase; and Summaries And Recommendations which should include statements of community policy, land use plan, land use ordinances and regulations, capital improvements program, and other recommendations arrived at during the formulation of the master plan. Citizen Participation

The planning board must recognize its responsibility to keep the public informed and involved throughout the master planning process. A proposed master plan is not likely to win much public support if the public has not been kept aware of or had an opportunity to have input during the preparation of the master plan. A citizen participation plan should be devised at the very outset of the master planning process. There are a number of ways to seek citizen participation, including questionnaires, workshops, citizen study committees, the media, the publication and distribution of informative and educational material, and through speaking engagements by individual planning board members with local civic groups. 
The citizens group should include a broad representation from the community. The greater the numbers and interests that are represented, the greater the credibility of the group within the community which, in turn, reflects on the credibility of the master plan developed by that group.

Adoption And Amendment of The Master Plan

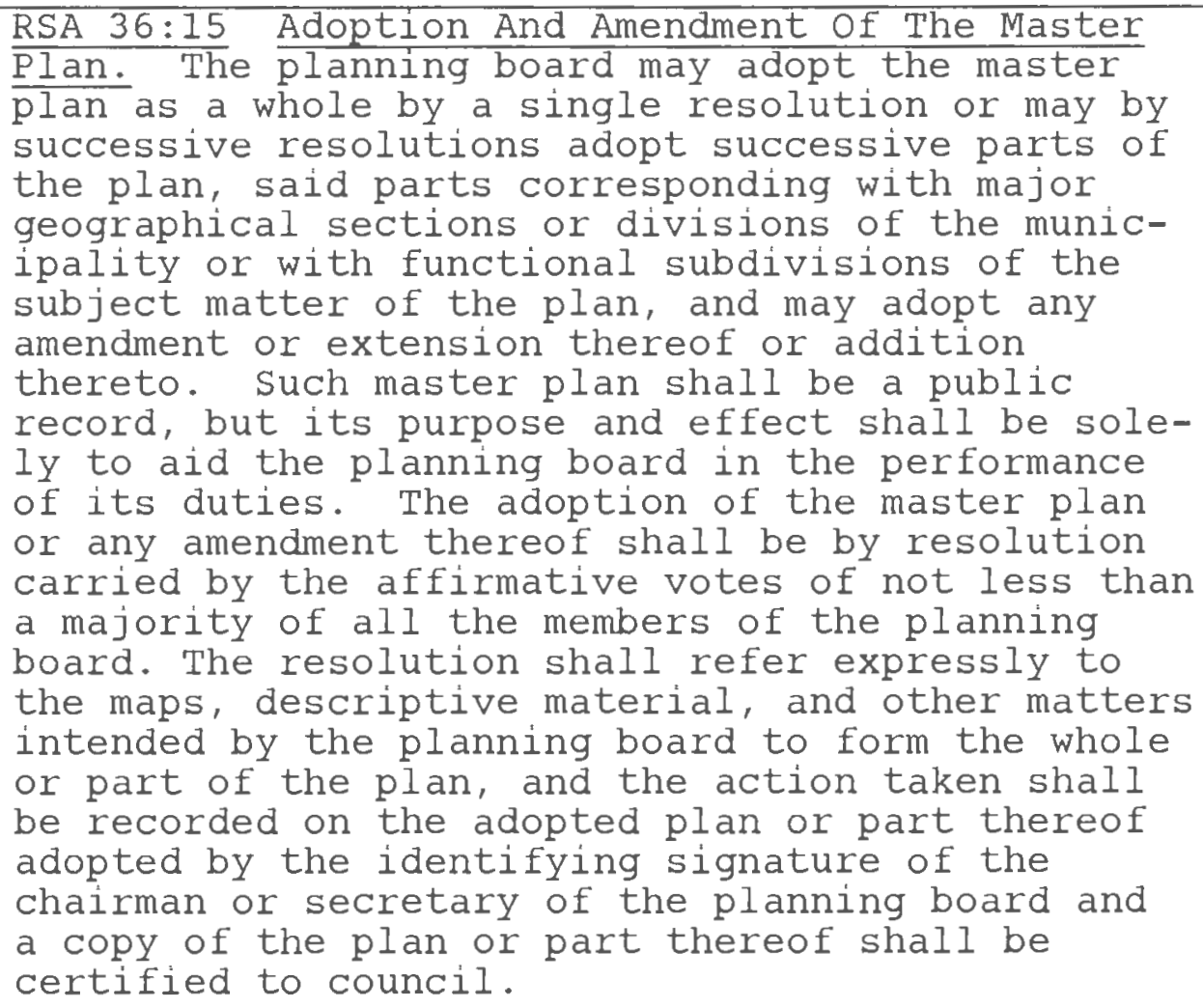

The planning board should hold a public hearing to receive public comments on the final version of the proposed master plan before voting on a resolution to adopt the master plan. To adopt the master plan requires a majority of the members of the planning board voting in favor of the resolution. If the resolution passes, the chairman or secretary of the planning board is authorized to 
sign it, and then must present a signed copy to the respective body: City Council, Board of Selectmen, or Village Distric Commissioners, whichever is appropriate.

Amendments of or additions to the master plan should also be adopted by resolution after receiving public input, signed by the chairman or secretary of the planning board, and then given to the appropriate local body. The planning board should endeavor to distribute copies of the adopted master plan to all appropriate municipal boards and commissions, regional and state agencies; and, to make it conveniently available to all citizens of the community in such places as the public library, municipal offices, and other appropriate locations.

Writing and adopting a master plan is one thing, seeing that it is implemented is another thing. A master plan has no practical value if its goals and policies are not referred to when making community development decisions. And, if the master plan's recommendations are not implemented, its preparation has been an exercise in futility.

The planning board should establish a "feedback" mechanism, a way of monitoring the implementation of the recommendations contained in the master plan. A suggested way of doing this is to organize the plan recommendations under three categories based on an expected time frame during which time a particular recommendation should be implemented: short-range (within one year); intermediate-range ( 1 to 3 years) and, long-range ( 3 to 5 years). It may also be a good idea for the planning board to assign a subcommittee of its members the responsibility of tracking the progress of plan implementation. 
Planning is a process of continually adapting to change, and therefore, the planning board should periodically re-evaluate the policies and recommendations set forth in the master plan, and, from time-to-time, update and/or amend the master plan to reflect changes in community attitudes and local conditions.

Legal Effect of The Master Plan

The principal purpose and effect of the master plan is to aid the planning board in the performance of its duties. The master plan is not legally enforceable in itself, and affects the community only when its policies and guidelines are translated into ordinances and regulations, or when the community either appropriates, or acquires through grants, the necessary funds to undertake a development project and/or a public service program that implements one or more of the master plan's recommendations. Where To Get Technical Assistance

In this handbook no attempt has been made to give directions or advice on how to actually prepare a master plan. That is because a number of "how-to-do-it" manuals have already been published. Some of these manuals are: The Land Book; Guiding Growth: A Handbook For New Hampshire Townspeople; and, Growth Management (volumes I and II). Another very good "do-it-yourself" manual entitled, Comprehensive Planning Guide For Local Planning Boards, can be obtained by writing to the Penobscot Valley Regional Planning Commission, 31 Central street, Bangor, Maine 04401. The American Planning Association, located at Lock Box 97774, Chicago, Illinois 60690, has an extensive library of Planning Advisory Reports that address a wide spectrum of planning issues 
applicable to the master planning process. These reports can be purchased for a nominal price.

The New Hampshire regional planning commissions provide communities with local planning services. Trained staff can assist the planning board in preparing the master plan, coordinating public participation, and implementing the policies and plans developed. Other agencies which provide general technical assistance to New Hampshire communities are the office of the state Planning, New Hampshire Municipal Association, and the New England Municipal Center. Various state agencies can provide communities with specific technical assistance as it relates to a specific issue or problem. 
FOOTNOTES FOR CHAPTER THREE

15. Smith, p. 10 
CHAPTER FOUR: ZONING

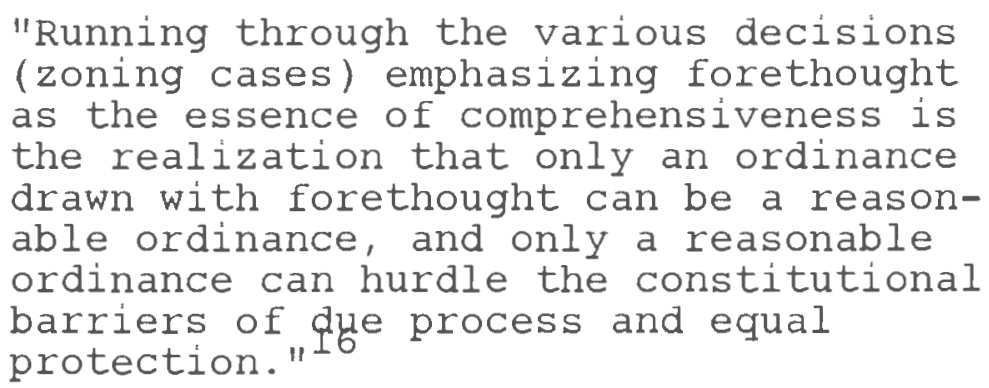

What Is Zoning

Zoning is an exercise of the police power of the state, and its political subdivisions, to enact legislation protecting the health, safety, morals and the general welfare of its citizens. RSA 31:60 of New Hampshire's Zoning legislation empowers communities to adopt zoning regulations (See Appendix B for a complete reprint of the Zoning legislation).

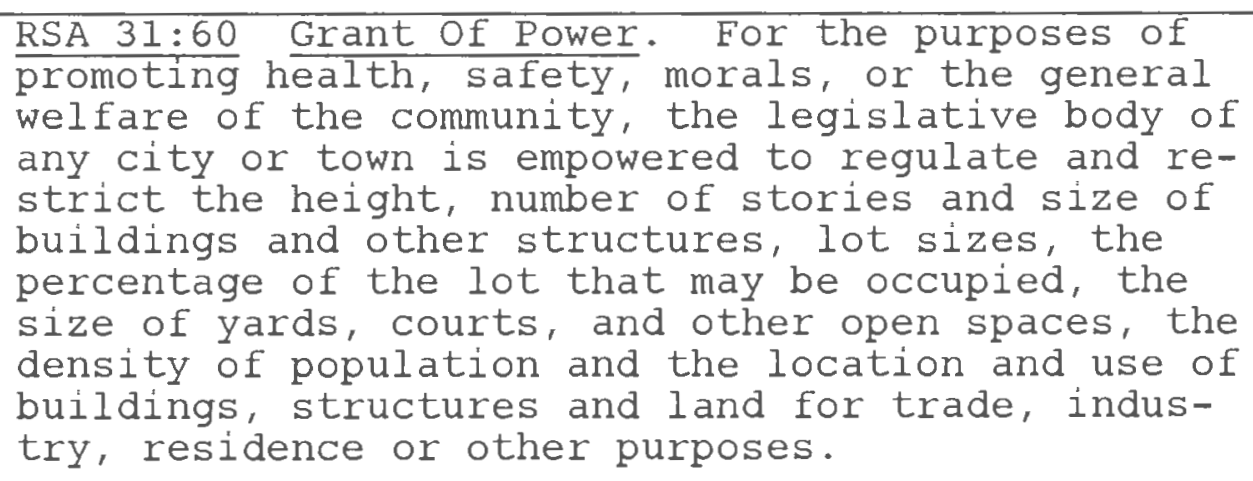
promoting health, safety, morals, or the general welfare of the community, the legislative body of any city or town is empowered to regulate and restrict the height, number of stories and size of buildings and other structures, lot sizes, the percentage of the lot that may be occupied, the size of yards, courts, and other open spaces, the density of population and the location and use of buildings, structures and land for trade, industry, residence or other purposes.

Zoning is essentially a means of insuring that the land uses of a community are properly situated in relation to one another, providing adequate space for each type of development, and the affording of adequate light, air and privacy.

Another aspect of zoning is the division of a community into districts ; 
RSA 31:61 Districts. For any or all of said purposes the local legislative body may divide the municipality into districst of such number, shape and area as may be deemed best suited to carry out the purpose hereof; and within such districts it may regulate and restrict the erection, construction, reconstruction, alteration, repair, or such use of buildings, structures, or land. All such regulations shall be uniform for each class or kind of buildings throughout each district, but the regulations in one district may differ from those in other districts.

and, the regulation within those districts of:

1. Height and bulk of buildings

2. Area of a lot which may be occupied

3. Density of population

4. Use of buildings - residence, commercial, or industrial

A zoning ordinance, in its construction, must meet the constitutional standards of the New Hampshire state Constitution (Part I Articles 2 and 12 ) and the legislative requirements of the New Hampshire Zoning Enabling statute. In broad terms, these requirements are:

1. Within a district the regulations must be uniform for each class or kind of use or buildings.

2. The zoning ordinance must cover entire jurisdictional area of the community, not single out a small area.

3. Zoning regulations must be reasonable in their application to particular properties.

4. There must be a reasonable basis for classifying particular areas differently from others. 
4. There are legal limits to a town's ability to restrict growth:

- Good faith efforts to increase the capacity of municipal services should accompany growth controls.

- Each municipality should bear its fair share of the burden of increased growth.

- Growth must be reasonable and non-discriminatory.

- Controls must not be imposed simply to exclude outsiders, especially outsiders

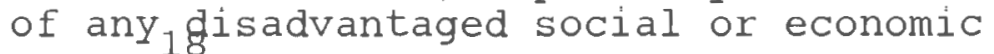
group.

The New Hampshire legislature, building on the legal foundations laid down by the New Hampshire Supreme Court, passed legislation in 1979, that embodies the guiding principals set forth in the Beck V. Raymond decision, empowering New Hampshire municipalities with the authority to regulate and control the timing of development.

RSA 31:62-a Growth Management: Timing of Development. The legislative body of a city or town may further exercise the powers granted under this subdivision to regulate and control the timing of development. Any ordinance imposing such control may be adopted only after a preparation and adoption by the planning board of a master plan and capital improvement program and shall be based upon a growth management process intended to assess and balance community development needs and consider regional development needs.

The legislature also recognized that under certain unusual circumstances, such as an unexpected rapid rate of growth because of factors beyond the community's control, a community should be allowed to adopt interim growth management regulations. 
5. Although they generally may not be expanded, prior non-conforming uses must be allowed to continue in each district.

6. There must be established a zoning board of adjustment to provide relief from the literal enforcement of the regulations where it creates an undue hardship to the landowner, and to grant relief would not be contrary to the spirit of the regulations.

In Appendix D there is offered a suggested format for the organization of a zoning ordinance.

Zoning is a legal and administrative device for implementing the master plan. New Hampshire's Zoning Enabling statute requires that the zoning ordinance be made"in accordance with a master plan".

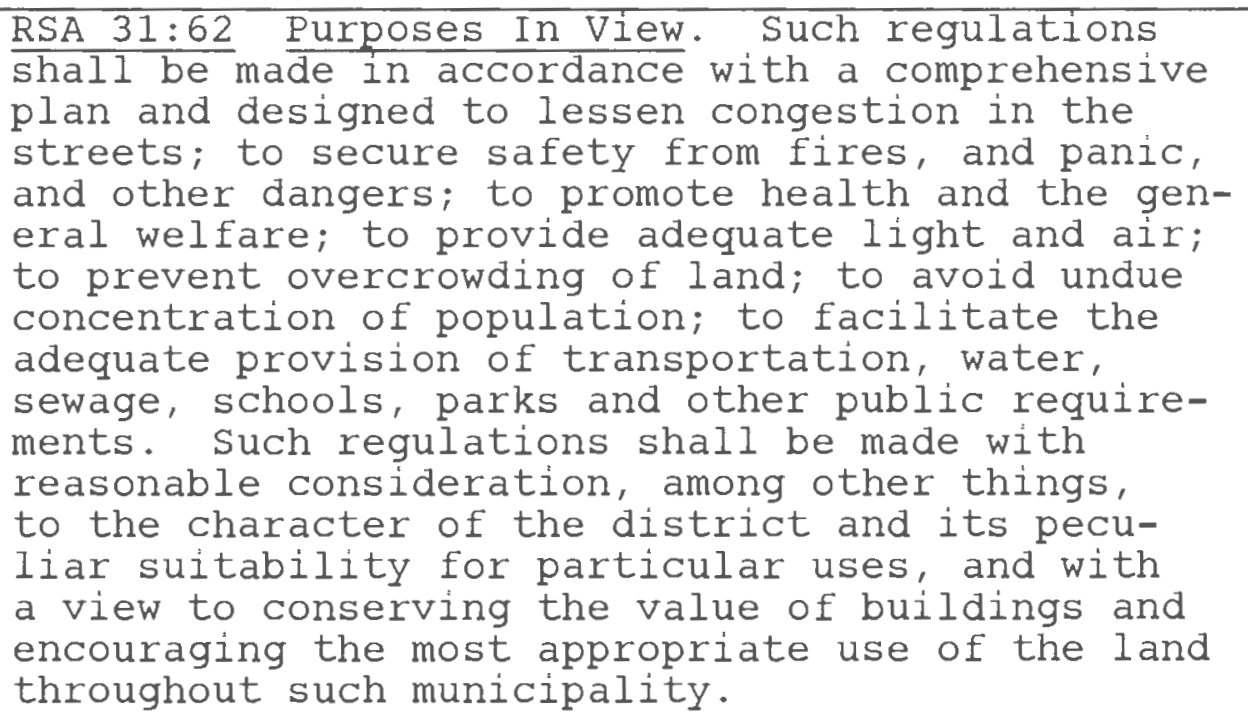

The phrase, "in accordance with a comprehensive plan" comes from the standard state Zoning Enabling Act (1926). In that Act, Comprehensive plan refers to a comprehensive study of the community prior to the adoption of a zoning plan. The intent of the "in accordance with a comprehensive plan requirement is to: 'prevent haphazard or piecemeal zoning'". 17 
Planners, lawyers, and the courts have, over the years, used the terms "comprehensive plan" and "master plan" interchangeably, but they really mean two different things. A comprehensive plan refers to a comprehensive zoning plan meaning that all areas of the community are included in the zoning plan while a master plan involves such analyses as population studies, housing studies, adequacy of public facilities which when taken together serve as a basis for establishing the community's growth policies and recommendations for implementing those policies.

New Hampshire communities do not have to have a master plan in order to be in compliance with the statutory requirements of RSA 31:62. A comprehensive zoning plan which may consist of a land use plan is sufficient. However, a community would need a master plan if it decided to adopt a growth management ordinance. Zoning Powers of The Planning Board

The planning board, once formed, assumes all the powers which were granted by law to the zoning Commission (RSA 36:11).

And further, the planning board is authorized to recommend to the legislative body amendments to the zoning ordinance (RSA 36:12).

Growth Management: Timing of Development

The concept of "timed development" is premised on the argument that communities should be able to control the rate of growth so that they may provide for, in a fiscally responsible manner, the additional public improvements necessary to service the new developments. Interest in timing community growth has been encouraged due to unsuccessful U.S. Supreme court challenges to growth management systems that were instituted in the cities of Ramapo, New York (1972) and Petaluma, California (1974). 
New Hampshire communities became interested in the timing of development through growth management systems because of the rapid and unprecented rate of growth in the southeastern tier of the State. Several communities adopted growth management ordinances which, in some cases, were subsequently challenged in the courts. Richard Beck v. Town of Raymond (1978) is the leading and most definitive decision on the legality of growth management ordinances in the state of New Hampshire. The town's ordinance limited the number of building permits that could be annually issued based on acreage. The supreme court struck down the town's ordinance for the following reasons: it was adopted incorrectly; it was not based on a local master plan; and, it did not recognize regional housing needs.

The court, however, in its ruling, sanctioned the adoption of a growth management ordinance by New Hampshire communities provided that the following guiding principals are observed.

1. Towns have the authority to enact land use measures under the general police powers of RSA 31:39 and the Zoning Enabling legislation of RSA 31:60-89. The authority to regulate land use under RSA 31:39 should be restricted to limited types of land use controls specified in the legislation. Comprehensive zoning regulations, as part of an overall regulatory scheme, should be enacted under RSA 31:60-89.

2. While a town has the right to impose reasonable limitations on growth through zoning, the zoning regulation must be based on a master plan.

3. Towns cannot refuse to grow and the key to growth management is comprehensive planning. Comprehensive planning with a solid scientific, statistical basis is the key element in land use regulation in New Hampshire. 
RSA 31:62-b Growth Management: Interim Regulations. I. In unusual circumstances requiring prompt attention and for the purpose of developing or altering a growth management process under RSA 31:62-a, or a master plan or capital improvement program, a city or town may adopt an ordinance imposing interim regulations upon development as provided in this section.

The following requirements must be met in order for a community to legally adopt interim growth management regulations:

1. The presence of unusual circumstances must be supported by facts.

2. At least one public hearing must be held, giving residents a 14 days notice of such hearing.

3. The notice of the hearing must include a text or adequate statement of the proposed interim regulations.

4. The legislative body must act on the proposed regulations within 45 days after the posting of the public hearing notice.

5. Interim regulations may not be in effect for a period exceeding one year.

It needs to be stressed that a planning board and its community cannot simply adopt interim regulations without going the next step which is to develop a growth management process that is based on a master plan and a capital improvement program. A failure to do so will result in those interim regulations being challenged in court and struck down as in the case of Beck V. Raymond. 


\title{
PROCEDURAL STEPS INVOLVED IN THE ENACTMENT OF
}

\section{A ZONING ORDINANCE AND AMENDMENTS}

Method of Enactment or Amendment In Cities

\begin{abstract}
RSA 31:63 Method of Enactment In Cities. The legislative body of a city shall provide for the manner in which such regulations and restrictions and the boundaries of such districts shall be determined, established and enforced, and from time to time amended. No such regulations, restriction or boundary shall become effective or be altered until after a public hearing in relation thereto, at which parties in interest and citizens shall have an opportunity to be heard. At least fourteen days notice of the time and place of such hearing shall be published in a paper of general circulation in such city; the fourteen days shall not include the day of publication nor the day of the meeting, but shall include any saturdays, sundays and legal holidays within said period.
\end{abstract}

The authority to create the zoning ordinance rest with the City Council. At the hearing on the proposed ordinance, the city Council must consider the opinions of all citizens of the city, and anyone else who may have a legal interest which would be affected by the proposed ordinance or amendments. The purpose of the hearing is to permit changes to be made to the proposed ordinance or amendment to reflect the desires of the city's residents.

METHOD OF ENACTMENT OR AMENDMENT: TOWNS AND VILLAGE DISTRICTS

Village Districts

According to the provisions of RSA 31:63-a, a village district must be specifically authorized by the New Hampshire state Legislature to enact a zoning ordinance. Once a village district has been so authorized, it is also authorized to make future amendments to the zoning ordinance. 
Towns

Towns are authorized under RSA 31:63-a to enact a zoning ordinance or amendment subjec to the following procedural steps.

1. Public Hearings - The planning board must hold at least two public hearings. Each hearing must be announced at least fourteen days in advance by publication in a paper of general circulation and by the posting of a legal notice in at least two places.

2. First Public Hearing - The planning board must consider and vote on any changes and amendments proposed by those who attend. The notice of the second hearing must adequately describe any changes or amendments which the planning board has voted to make.

3. Second Public Hearing - The planning board may consider making minor textual modifications and editorial revisions to the proposed ordinance or amendment, but may not change the substance of the proposed ordinance or amendment.

4. Filing Notice - At least four weeks before the town (or viliage district) is to vote on the proposed ordinance or amendments, official copies must be placed on file, available to the public, at the office of the town (or village district) clerk. A copy must be on display at the time and place of voting.

5. Placement on Ballot - All zoning questions must be voted on by ballot. The form of the ballot shall be as prescribed by RSA 59:12-a.

In appendix $D$ there is an illustrative representation of the procedural steps for the adoption or amendment of a town zoning ordinance. All zoning questions, whether it be in a village district or town, must be voted on by ballot.

Zoning Amendment By Citizen Petition

RSA 31:63-b By Petition. Upon petition of twentyfive voters for an amendment to a zoning ordinance, the zoning commission or the planning board, shall proceed and submit the amendment or amendments to the voters of a town or village district as prescribed in section 63-a. 
The planning board must accept all petitions provided that it has the signatures of twenty-five registered voters and that wording of the question conforms with the requirements of RSA 31:63-6. The planning board cannot in any way alter the wording of a citizen's zoning petition.

There are four other important notes about citizen petitions that planning board members should know and remember: First, once a person has signed his name to a petition, he cannot remove his name from the petition; second, planning boards are required to note their recommendation to the voters on citizen petitions; third, citizen petitions for zoning amendments can only be submitted to the voters at the annual town or village district meeting; and fourth, there must be the signature of twenty-five registered voters in order for the petition to be valid.

$\underline{\text { Protest }}$

Citizens may "protest" the adoption of a proposed zoning ordinance or amendment effectively requiring a favorable vote of two-thirds of the voters in order to be passed. The procedure for a "protest" is prescribed in RSA 31:64.

RSA 31:64 Changes In Regulations, etc. I. Such regulations, restrictions and boundaries may from time to time be amended or repealed. In case of a protest against such change, signed by the owners of 20 percent either of the area of the lots included in such proposed change, or of those immediately adjacent in the rear thereof extending 100 feet therefrom, or of those directly opposite thereto extending 100 feet from the street frontage of such opposite lots, such amendment or repeal shall not become effective except by the favorable vote of $2 / 3$ of all the members of the legislative body of such municipality present and voting. 
RSA 31:64 (cont.) II. In order to have any protest considered pursuant to paragraph I, the signed petition shall be submitted to the selectmen at least 24 hours prior to the town meeting, and the moderator shall announce that a protest petition has been received at the opening of the town meeting.

Board of Adjustment

Any community that adopts a zoning ordinance must also appoint a Board of Adjustment.

RSA 31:66 Board of Adjustment. Such local legis-
lative shall provide for the appointment of a
board of adjustment, and in regulations and re-
strictions adopted pursuant to the authority
hereof shall provide that the said board may,
in appropriate cases and subject to appropriate
conditions and safeguards, make special excep-
tions to the terms of the ordinance in harmony
with its general purpose and intent and in ac-
cordance with general or specific rules therein
contained.

This handbook does not discuss the powers and duties of the Board of Adjustment as there already is an excellent Handbook in print on that subject entitled, The Board of Adjustment In New Hampshire: A Handbook For Local Officials (1979). It is available from the New Hampshire office of state Planning.

\section{OFFICIAL MAP OF THE MUNICIPALITY}

What Is An Official Map: RSA 36:16-18

The official map can be a useful minicipal land management tool. It is a map drawn from surveys taken in the community that shows to scale the exact location of the exterior lines of existing and proposed streets and the proposed extension, widening, narrowing, abandonment, or relocation of existing streets. The 
official map may also show the exterior lines of existing and proposed municipal parks and sites designated for future public facilities.

The official map has three basic functions:

- Inventory: the map shows the precise location of future improvements, and the exact boundaries of the public right-of-way (surveyed lines).

- Future location: the map designates sites for proposed future streets, parks, schools, and other public facilities to be acquired by the municipality.

- Prohibition against building: once a site has been desingated on the official map, further construction or development within the identified boundary becomes unfeasible since the municipality then has the first option to acquire the land.

Once a site or right-of-way is reserved by designation on the official map, community acquisition should proceed in a timely manner to avoid "property taking without just compensation" claims. Adoption of An Official Map

The legislative body of the municipality may authorize the planning board to make and certify to the legislative body an official map provided that:a master plan which includes a "major street" plan has been adopted by the municipality, or the making of the master plan is substantially complete and includes a "major street" plan. The establishment of an official map is a complex and involved process. In fact, to date only one New Hampshire municipality, the city of Concord, has adopted an official map.

The steps that must be followed when establishing an official map as provided for in RSA 36:17 are summarized below. 
1. The planning board adopts a master plan which includes a major street plan or amends the master plan to include a major street plan.

2. If a community does not have adequate maps, the town (village district) meeting or city council authorizes street surveys in all or portions of the community.

3. The planning board certifies the major street plan to the town (village district) meeting or city council.

4. The town (village district) meeting or city council adopts the major street plan as the official map.

5. The official map is certified by the town (village district) or city clerk and filed with the Register of Deeds in the County in which the municipality is situated.

Amendments to the official map must be adopted in the same manner as in the original adoption of the official map (RSA 36:18). 
16. Charles Harr, "In Accordance With A Comprehensive Plan," Harvard Law Review, 1154 (1955).

17. Advisory Committee on Zoning, A Standard State Zoning Enabling Act (Washington, D.C.: U.S. Department of Commerce, 19.26).

18. N.H. Office of state Planning, Planning and Development Techniques (Concord, New Hampshire: Office of state Planning, 1979), pp. 72-73. 
CHAPTER FIVE: SUBDIVISION AND SITE PLAN REVIEW REGULATIONS

"The effectiveness of subdivision regulations as a growth management tool has increased in the 1970's so that regulations exceed the internal requirements of the subdivision and its residents. The regulations now account for the relationship of the subdivision to its environment and the master plan."I9

What Is A Subdivision

The term "subdivision" is defined in the New Hampshire Planning legislation under RSA 36:1-VIII.
RSA 36:1-VIII "Subdivision" means the division of lot, track, or parcel of land into two or more lots, plats, sites or other division land for the purpose, whether immediate or future, of sale, rent, lease, condominium conveyance or building development. It includes resubdivision and, when appropriate to the contest, relates to the proc- ess of subdividing or to the land or territory subdivided. The division of a parcel of land held in common and subsequently subdivided into parts among several owners shall be deemed a subdivision under this chapter.

Minor Subdivision

Some municipalities have included a special provision for "minor subdivisions" in their subdivision regulations. A minor subdivision is generally defined as: a division of land that has frontage on an accepted road into lots with no potential for resubdivision and requiring no new roads, utilities or other municipal improvements. The number of lots that may be created by subdivision and still be considered a minor subdivision varies among communities. Some communities only allow two, while other communities allow four. 
Municipalities include such a provision in their subdivision regulations because: first, a minor subdivision does not require the same level of review as a several lot subdivision, and therefore, can generally be processed in one hearing; and second, it reduces the planning board's work load leaving more time available for general planning related to the community's future development. Grant of Power To Regulate The Subdivision of Land

New Hampshire's Planning legislation allows municipalities to empower their planning board to adopt and administer subdivision regulations.

RSA 36:19 Grant of Power To Regulate. A municipality may by ordinance or resolution authorize and empower the planning board to approve or disapprove, in its discretion, plats showing streets, or the widening thereof, or parks.

It is the responsibility of the municipal clerk (city, town or village district) to file with the register of deeds a certificate or notice indicating that the municipality has adopted an ordinance or resolution empowering the planning board to approve or disapprove subdivision plats. If such certificate or notice is not appropriately filed, any action taken by the planning board will have no legal force or effect.

$\underline{\text { Recording of Plats }}$

Once a municipality has filed a certificate or notice in accordance with RSA 36:19, no subdivision plat may be filed or recorded with the register of deeds without the planning board's written endorsement on the subdivision plat (RSA 36:20). 
Method of Adopting Subdivision Regulations

RSA 36:21 Subdivision Regulations: General. Before exercising the powers referred to in section 19 hereof, the planning board shall adopt regulations governing the subdivisions of land within its jurisdiction.

In accordance with RSA 36:22, the planning board is required to publish the regulations in accordance with the requirements for the publication of local ordinances and, before adoption, hold at least one public hearing.

Suggested procedural steps to follow when adopting subdivision regulations are:

1. Conduct several workshops encouraging maximum citizen participation.

2. Post the notice of the hearing in at least two public places and publish the full text or adequate statement of the regulations in a local paper of general circulation.

3. The public notice should include the time, place and date of the public hearing.

City planning boards should review the city charter to determine what the procedural guidelines are for city boards and committees when adopting municipal regulations.

Validity of Adopted Subdivision Regulations

Subdivision regulations and any subsequent amendments, in order to be valid, must be certified by a majority of the planning board members and filed with the municipal clerk, board of selectmen or city council (RSA 36:21-a). Additionally, RSA 36:22 provides that the adopted subdivision regulations and any subsequent amendments must be filed with the register of deeds. 


\section{SUBDIVISION REGULATIONS}

What Are Subdivision Regulations

Subdivision regulations are locally adopted requirements imposed on a landowner who wants to subdivide a tract of land for sale or building development. These regulations may, as set forth in RSA 36:21, may provide for:

1. protection against scattered or premature subdivision

2. harmonious development of the municipality and its environs

3. proper arrangement of streets in relation to existing or planned streets

4. open space, parks and playgrounds adequate to meet the recreation needs of future neighborhoods

5. suitably located streets of adequate width to accomodate existing and future traffic, and that also provide for safe passage of emergency vehicles.

6. adequate light and air

7. dedication of land for parks, playgrounds, or other recreational purposes

8. minimum lot areas in conformance with the local zoning ordinance

9. adequate on-site sanitary facilities

10. other provisions which will tend to create conditions favorable to health, safety and convenience

11. posting of performance bond (RSA 36:22)

Premature Subdivision

Haphazard and scattered subdivision of land can put a severe strain on the municipal budget to provide those new developments with adequate public utilities and services. RSA 36:21 empowers municipalities to protect against premature subdivisions that can- 
not be provided with adequate public utilities and services without burdening the municipal budget. Such regulations are subject to the same legal requirements for the adoption of growth management provisions in local zoning ordinances. The regulations must be made in accordance with the following:

1. a master plan which includes public policies regarding the extension of public utilities and services to undeveloped areas of the community.

2. a capital improvement program that includes a schedule for extending public utilities and services to undeveloped areas of the community.

3. a definition of premature subdivision in the regulations.

4. criteria for determining whether or not a proposed subdivision is premature.

The City of Lebanon, New Hampshire adopted the following provision in their subdivision regulation for determining whether or not a subdivision is premature.

"205.2 Causes. The following items shall be considered in determining whether the proposed subdivision is scattered or premature and the subdivider may be required to have studies made under guidelines established by the planning board to determine the effect that the proposed subdivision may have on:

A. Distance from nearest elementary school

B. Capacity of school system and effect on school bus transportation

C. Adequacy of access street(s) and/or sidewalk(s)

D. Adequacy of water supply for domestic and fire fighting purposes

E. Potential health problems due to on-site sewage systems and for water supply 
F. Potential fire protection problems due to location and/or special conditions relative to type of use

G. Potential special policing problems

H. Potential drainage problems both on the site and downstream

I. Cause an excessive expenditure or public funds

J. Other potential problems within the meaning or the purpose of this section"

The planning board should also consider setting specific criteria for each of the above items included in Lebanon's regulations. Appendix $\mathrm{F}$ contains a sample list of criteria for assessing the impact of a subdivision.

Dedication of Land

Planning boards may require developers to make land dedications for open space, parks or playgrounds. The planning board should impose such requirements if it is deemed to be in the public interest, but the planning board must be reasonable in its requirements.

Procedural Reguirements of Subdivision Review

Planning boards must adhere to the procedural requirements as set forth in RSA 36:23. These procedural requirements are summarized below:

1. plans must be placed on the planning board agenda within 30 days of its submittal

2. plans must be either approved or disapproved within 90 days of the submittal of a completed application.

3. planning baord may apply to the board of selectmen or city council for an extension not to exceed 90 days 
4. failure to act on a plan within 90 days of its submittal is deemed approval of that plan and an officer of the municipality (designated in the ordinance creating the planning board) shall issue a "certificate of failure" which enables the applicant to record the plan with the register of deeds

5. whenever a plan is considered by the planning board, the applicant and abutters shall be notified by certified mail not less than five days from the date fixed for the hearing

6. the names and addresses of the applicant and abutters shown on the plan

7. the planning board shall keep a proper record of decisions made to approve or disapprove a plan

8. the cost of notifying abutters shall be paid for by the applicant

State Agency Review of Subdivision Plans

All subdivisions in the state of New Hampshire must be approved by the New Hampshire water Supply and Pollution Control Commission (WSPCC) before any lots can be sold (RSA 149:E:2). Subdividers must submit their preliminary subdivision layouts to the WSPCC in addition to the local planning board. It is the subdividers responsibility, not the planning board's, to obtain approval from the Commission, although the planning board should advise the subdivider of his responsibility.

Status of Approved Subdivisions

Approved subdivisions become a part of the official map (RSA 36:24). However, the approval of a subdivision plan does not constitute municipal acceptance of streets or other open space shown on the approved plan.

Acceptance of streets is approved by the legislative body after recommendation of the planning board. The planning board 
should not recommend a street for acceptance unless and until the street and other public improvements shown on the subdivision plan have been completed to community standards.

The planning board may require the developer to post a performance bond (RSA 36:22). The bond is placed in an escrow account and is released to the developer as segments of the subdivision improvements are completed. In the event that the developer failed for whatever reason to complete the subdivision improvements, the municipality may use the remainder of the bond to have those improvements completed.

Four Year Exemption

Once a subdivision plan is approved and properly recorded in the registry of deeds, it is exempt from any subsequent changes in the subdivision regulations and zoning ordinance for a period of four years provided that:

1. active and substantial development or building shall have commenced within twelve months of plan approval

2. development remains in full compliance of public health regulations

Municipalities can, irrespective of the four year exemption provision, impose stricter public health standards on an already approved subdivision if it finds it to be a necessity for the protection of the general public.

Erection of Buildings

RSA 36:26 provides that no building may be erected and no building permit may be issued to erect a building on a lot unless the lot has frontage on an accepted street. 
A person who wishes to erect a building on a lot that does not have frontage on an accepted street may make an appeal to the board of adjustment for grant of relief from such requirement. The board of adjustment may grant such relief it if finds that such action will not cause harm to the public or cause problems in the carrying out of the masterplan.

Court Review

Any person aggrieved by a planning board decision concerning a subdivision plan may petition the superior court for relief from that decision.

RSA 36:34-V. The court may reverse or affirm, wholly or partly, or may modify the decision brought up for review when there is an error or law or when the court is persuaded by the balance of probabilities, on the evidence before it, that said decision is unreasonable.

The planning board should not make arbitrary or capricisious decisions. All decisions must be supported with well documented facts.

Municipalities interested in establishing or amending subdivision regulations should refer to the Handbook of subdivision Practice prepared by the New Hampshire Office of state Planning as a guide for the preparation and administration of subdivision regulations. Municipalities should also consult with their regional planning agency for advice and technical assistance.

Appendix G contains a suggested format for organization of the subdivision regulations. 


\section{SITE PLAN REVIEW REGULATIONS}

Municipalities that have adopted a zoning ordinance and subdivision regulations may further empower the planning board to approve or disapprove site plans for non-residential uses and multi-family dwellings that include three or more dwelling units. (RSA $36: 19-a-I)$

The planning board must adopt site plan review regulations including:

RSA 36:19-a-II. (a) Procedures the board will
follow in reviewing site plans, including any
notice and hearing requirements.
(b) The purposes of site plan review and the
general standards and requirements with which
proposed developments must comply.
(c) Provisions relative to guarantees for per-
formance, including bonds or other security.

The planning board should follow the same procedural steps as for the adoption of subdivision regulations as outlined on page 55 . A certified copy of the site plan review regulations must be filed with the municipal clerk (city, town or village district), and also with the registry of deeds.

Site plan review is an important land use control that enables communities to insure that commercial, industrial, and multifamily developments are developed in harmony with the community. These types of development have a far greater impact to the site, area adjacent to the site, and to the community in general.

while the items of concern are similar to those of subdivision review, there are some additional items that the planning board should consider: 


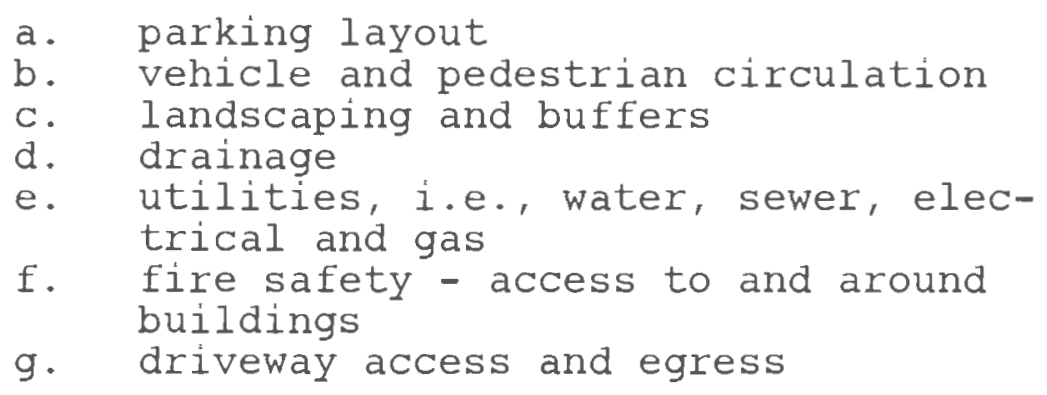

A typical site plan is illustrated in Exhibit 2. It serves to draw your attention to the various aspects of site development and how they inter-relate.

A model site plan review regulation is presented in the New Hampshire Office of state Planning publication entitled: Growth Management: Volume II. Planning boards may also obtain technical assistance from regional planning agencies.

A site plan review checklist developed by the salem, New Hampshire Planning Board is contained in Appendix $\mathrm{H}$. 


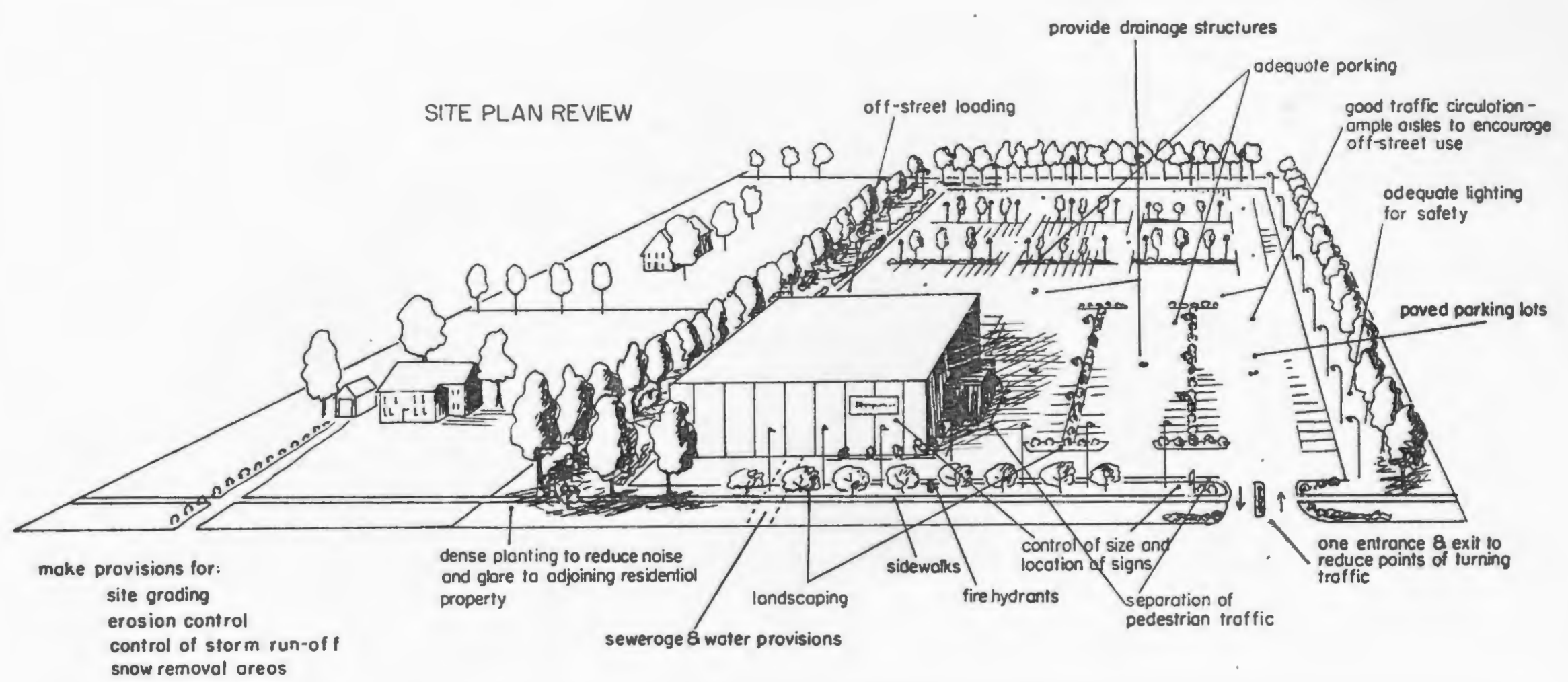


FOOTNOTES FOR CHAPTER FIVE

19. Gleason, Ball, Chinn, Einsweiler and Meagher, Urban Growth Management Systems: An Evaluation of Policy Related Research, p. 4 .

20. N.H. Office of State Planning, Planning And Development Techniques (Concord, N.H.: Office of state Planning, $1979)$, p. 113 
CHAPTER SIX: SUMMARY OF OTHER RELEVANT STATUTES

New Hampshire planning boards are governed by New Hampshires Planning and Zoning legislation. However, there are a number of other statues that have some significance for planning boards in terms of their general community planning function. These statutes are summarized below.

RSA 31:89-a Authority To Establish Historic Districts. Municipalities may establish historic districts and create a Historic District Commission whose responsibility it is to review and act upon all building permits for properties within those districts. The commission shall request recommendations from the planning board concerning an applicant's proposed action within a district.

RSA 31:92 Eminent Domain. A municipality may take property by eminent domain, if it cannot acquire such property through agreement, provided that the property owner receives just compensation for his property.

RSA 31:103 Interim Zoning Ordinance. A town that does not have a zoning ordinance may, upon application to the Board of selectmen by five percent of the voters, call a special town meeting to see if the town will adopt the provisions of RSA 36-C entitled Emergency Temporary zoning and Planning ordinance.

RSA 31:103 Liability For Municipal Executives. No municipal executive or member or a municipal board or commission, including planning boards, may be held liable for civil damages for any vote, resolution or decision made by that person while acting in his official capacity provided that it is done so in good faith and it is within the scope of his authority. 
RSA 31:109 Local Option For Oil Refinery Siting In Towns.

Notwithstanding the provisions of any other law, an oil refinery may not be located in any town without the vote of approval of a majority of voters present and voting on the question at an annual or special town meeting.

RSA 35:1-18 Capital Reserve Funds. Municipalities may establish capital reserve funds for the financing cost of the construction or reconstruction of capital improvements (sewer, water, etc.). Chapter 35 has relevance for planning boards in that one of their powers, under RSA 36:10, is to make recommendations for the erection of public facilities and improvements and the financing of those facilities and improvements.

RSA 36-A Conservation Commissions. Municipalities may establish a Conservation Commission whose responsibility is to promote and develop the municipality's natural resources.

RSA 36-C Interim Zoning ordinance. Chapter 36-C includes an interim zoning ordinance that a town which does not have a zoning ordinance may adopt as an Emergency Temporary Zoning and Planning Ordinance.

RSA 36-D Acquisition of Agricultural Land Development Rights.

Establishes an Agricultural Lands Preservation Commission under the N.H. Department of Agriculture. The committee is responsible for evaluating and accepting or rejecting cities proposed by a municipality. The state, municipality, or charitable organization may acquire the development rights of agricultural land, meaning the acquisition of the rights of the fee simple owner to construct on or otherwise improve the agricultural land in a way that renders the land unsuitable for agricultural use. 
RSA 79-A Current Use Taxation. A law that is intended to encourage the preservation of open space by requiring assessing officials to appraise open space land based upon current use value, not for its potential use value.

RSA 79-A:15 Discretionary Easements: Planning Board. An owner of land may apply in April to the planning board for a permit to convey a discretionary easement to the municipality. The planning board recommends to the municipality whether or not such request is consistent with the municipality's open space objectives. RSA 91-A Access to Public Records. This statute is commonly referred to as the "Right To know Law". It requires that all meetings of public bodies shall be open to the public. All decisions of public bodies must be made in public; and all records of those public bodies shall be available for public inspection.

RSA 149-E Sewage Disposal Systems. Requires that any person proposing to subdivide land and to construct subsurface waste disposal systems on those lots, or on a single lot purchased as such, must submit plans and specifications for the sewage disposal system to the New Hampshire water supply and Pollution Control Commission.

RSA 155-D Energy Conservation In New Building Construction. Architects and engineers must certify that all new buildings and structures conform to the standards of the "Model Code For Energy Conservation In New Building Construction".

RSA 155-E Local Regulation Excavations. Municipalities may adopt governing the excavation of land such as gravel pits. 
RSA 156:3-a Building Permits To Be withheld In Certain Cases.

The building inspector may not issue a building permit after the first posting of changes of a building code if the proposed building activity will not meet the requirements of the proposed changes. In addition, a building permit may not be issued after the first posting of proposed changes to the zoning ordinance if such proposed use will not meet the requirements of the proposed changes.

RSA 231:10 Construction And Reconstruction: Limitation. The state may not perform any road construction projects, except for highways laid out under the provisions of RSA 236, unless the municipality has adopted either a zoning ordinance or master plan. RSA 249:17 Driveways And Other Accesses To The Public Way. A driveway access permit must be obtained from the New Hampshire Department of Public Works and Highways in order to gain access onto any state-maintained highway. The planning board or selectmen of a municipality may adopt similar regulations governing access onto town roads.

RSA 253:17 Scenic Roads: Designation. Any road in a town, other than a class I or II highway, may be designated as a scenic road. Repair work on scenic roads shall not involve the cutting of trees or destruction of stone walls except with the prior written consent of the planning board or by any other office municipal body with control over scenic roads.

RSA 267-A Motor Vehicle Junk Yards. Municipalities may regulate the location and operation of motor vehicle junk yards in accordance with the provisions of chapter 267-A. 
RSA 356-B Condominium Act. This statute is quite lengthy including numerous requirements for the recording of condominium documents. Section five of this chapter is the most relevant portion of the statute for planning boards. It provides that municipalities may not prohibit condominiums because of form of ownership if the municipality already allows physically identical projects or developments (apartments). Municipalities may require a special use permit, special exception or variance for a condominium conversion if the property does not conform to zoning, land use or site plan regulations.

RSA 424 Airport Zoning. Chapter 424 is known as the 'Model Airport zoning Act'. It is a model airport zoning ordinance which municipalities may adopt in a manner set forth in the Act.

Chapter 31 of the New Hampshire Revised Statutes Annotated has to do with the power of municipalities to make by-laws for the protection of health, safety and general welfare of its' residents. Several sections of Chapter 31 are relevant to the planning board's general community function. These are itemized below.

$31: 15 \quad$ Town Forests

31:41 Open Air Motion Picture Theatres

31:41-a Motor Vehicle Racetracks

31:41-b Hazardous Pits

31:51 Shade Trees

31:102-a Temporary Sales Locations 
BIBLIOGRAPHY

Babcock, Richard F. The Zoning Game. Milwaukee, wisconsin: University of wisconsin Fress, 1966.

Routin, David R. "Comprehensive Planning: A Review of the I enature." 1977. (Faper written as a graduate student at the University of Rhode Island.)

Rrill, Frank P. "NH Economy Best In Frostbelt States." Manchester Inion I eader, 2February 1981, p. 1 .

Environmental Consulting Group, Inc. Growth Manaogement Volumes I and II. Concord, New Hampshire: N.H. Office of state Planning, 1977 .

Garland, Bill. "NH Is The Fastest Growing State In Northeast." Manchester Union Leader, 3 February 1981. Gilrain, Faul T. "Recent Developments In Land Use Regulation."

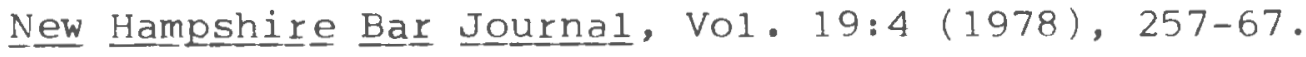

Goodman, William I.., and Freund, Eric C. Eringciples and

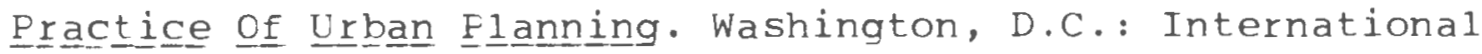
City Manaqers' Association, 1968. Hanslin Flanning Associates, Inc., The 므믐 Book . Concord, New Hampshire: N.H. Office of State Flanning, 1975. Maine State Planning office, Guidelines Eor local $\underline{1}$ Flanning Boards. Augusta, Maine: Maine State Planning Office, 1973. Melrose, John A. The Law of Zoning In The State of New Hampshire․ Manchester, New Hampshire: Lew A. Cummings Co., Inc., 1976. New Hampshire office of State Planning, The Board of Adjustment In New Hampshire: A Handbook For Local Officicials. Concord, New Hampshire: N.H. Office of State Planning, 1979. 
New Hampshire Office of State Planning, 티믐ing ang $\underline{\text { Development }}$

Techniques. Concord, New Hampshire: N.H. Office of State Planning, 1979 .

Penobscot Valley Regional Planning Commission, Comprehensive

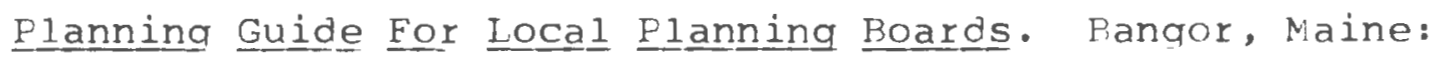
PVRPC, 1976.

Scott, Mel, American City Flanning. Berkley, California: University of California Fress, 1969.

Smith, Herbert $H$. The Citizen's Guide To Planning. West Trentor, New Jersey: Chandler-Davis Publishing Company, 1961. Smith, Herbert H. The Citizen's Guide To Zoning. West Trenton, New Jersey: Chandler-Davis Publishing Company, 1965.

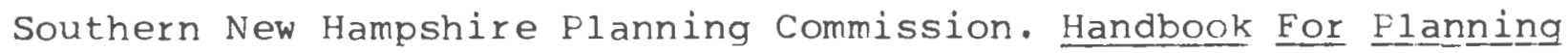
Boards and Zoning Boards of Adjustment. Manchester, New Hampshire: SNHPC, 1973.

Stein, Mark. Teaching Planning To Connecticut Townspeople. Storrs, Connecticut: Institute of Public Service University of Connecticut, 1977.

Technical Planning Associates. Handbook of Subdivision Practice. Concord, New Hampshire: N.H. Office of State Planning, 1972. The Planning Services Group, Inc. A Guide For Evaluating Develppment Proposals. Bow, New Hampshire: Central New Hampshire Regional Planning Commission, 1975.

Susan Redlich. Guiding Growth: A Handbook For New Hampshire Townspeople. Concord, New Hampshire: Society For The Protection of New Hampshire Forests, 1974. 
CHAPTER 36

New Hampshire Revised Statutes Annotated

PLANNING BOARDS

36:1 Definitions. For the purpose of this chapter certain terms are defined as provided in this section. Wherever appropriate the singular includes the plural and the plural includes the singular.

I. 'Municipality" or "municipal" means, includes and relates to cities, towns and village districts. 1935, 55:1

II. "Mayor" means the chief executive of the municipality, whether the official designation of his office be mayor, city or town manager, or otherwise. $1935,55: 1$

III. "Council" means the chief local legislative body of the municipality, whether it be officially designated council, mayor and council, board of mayor and aldermen, commission, village district, town meeting or by other title. $1935,55: 1$

IV. "Selectmen" means the board of selectmen of a town. 1935, 55:1

V. "District commissioners" means the board of commissioners of a village district or precinct. 1935, 55:1

VI. "Planning board" means, relates to and includes city, town, village district and regional planning boards, established under the provisions hereof. 1935, 55:1

VII. "Street" means, relates to and includes street, avenue, boulevard, road, lane, alley, viaduct, highway, free way and other ways. 1935, 55:1

VIII. "Subdivision" means the division of a lot, tract, or parcel of land into two or more lots, plats, sites, or other divisions of land for the purpose, whether immediate or future, of sale, rent, lease, condominium conveyance or building development. It includes resubdivision and, when appropriate to the context, relates to the process of subdividing or to the land or territory subdivided. The division of a parcel of land held in common and subsequently divided into parts arnong the several. owners shall be deemed a subdivision under this chapter. $1977,312: 1$

IX. "Abutter" means any person who owns land within 200 feet of the boundaries of the land under consideration. A way, as defined in RSA 259:1, XXXV, shall not be considered to be a barrier, but shall be included in the distance requirement for purposes of determining whether a person is an abutter. $1979,323: 1$

\section{MUNICIPAL PLANNING BOARDS}

$36: 2$ Grant of Power to Municipality. Any municipality is hereby authorized and empowered to create by ordinance a planning board and to make available to it the powers and duties herein prescribed. 1935, 55:2

36:3 Designation of Planning Boards. The planning board of a city shall be designated city planning board; of a town or village district, town or village district planning board; and of a region, regional planning board. 1935, 55:3 
36:5 Qualifications and Terms of Members.

I. In the case of towns, appointed or elected members of the planning board may also serve on any other municipal board or commission provided that no more than one planning board nember shall serve on the same board or commission. In the case of cities, appointed members shall not hold any other municipal office except that:

(a) One of such appointed members may be a member of the zoning board of adjustment:

(b) Either one appointed or one ex officio member nay be a member of the conservation commission, if one exists in the city, in accord with RSA 36-A:3;

(c) Either one appointed or one ex officio member may be a member of the historic district commission, if one exists in the city, in accord with RSA 31:89-d. $1975,228: 2$

II. The terms of ex officio members shall correspond to their respective official tenures, except in the case of cities that the term of the administrative official selected by the mayor shall terminate with the term of the mayor selecting him. The term of each appointed member shall be six years in the case of 9-member planning board, five years in the case of seven-member planning boards and four years in the case of five-member planning boards, except that the respective terms of five of the members first appointed to a nine-member or a seven-member planning board shall be one, two, three, four, and five years; and in the case of five-member planning boards that the respective terms of the four members first appointed shall be one, two, three, and four years. $1974,44: 1$

36:6 Removal of Members of Planning Board. Members of a planning board other than the members selected by council may, after public hearing, be removed by the mayor for inefficiency, neglect of duty, or malfeasance in office. Council, selectmen, or district commissioners may for like cause remove the members selected by them. Selectmen may for like cause remove an elected member. The mayor or the council, selectmen, or district commissioners, as the case may be, shall file with the city or town clerk, or clerk of the board of district commissioners, whichever is appropriate, a written statement of reasons for such removal. 1975, 228:3

36:7 Filling of Vacancies in Membership. Vacancies in the membership of a planning board occuring otherwise than through the expiration of a term shall be filled for the duration of the unexpired term, except if a vacancy occurs for an elected member pursuant to paragraph IV, then that vacancy shall be filled by the selectmen until the next election, all other vacancies shall be filled by the: $1077,532: 2$

I. Mayor for members selected or appointed by him.

II. Council in the case of a councilmanic member.

III. Appointing power which has been designated by the council in municipalities in which the mayor is not an elective officer.

IV. Selectmen for members selected or appointed by them or for an elected member. 
consult and advise with public officials and agencies, public utility companies, civic, educational, professional, research, and other organizations, and with citizens with relation to the protecting or carrying out of the master plan, and to make recommendations relating to the development of the municipality. The planning board shall have the right to accept and use gifts for the exercise of its functions. All public officials shall, upon request, furnish to the planning board, within a reasonable period of time, such available information as it may properly require for its work. The planning board, its members, officers, and employees, in the performance of their functions, may be authorized by ordinance to enter upon any land and make such examinations and surveys as are reasonably necessary and place and maintain necessary monuments and marks thereon. In general, the planning board may be given such powers as may be necessary to enable it to fulfill its functions, promote municipal planning, or carry out the purposes hereof; provided the total expenditures of said board shall not exceed the appropriation for its expenses. 1935, 55:13

36:11 Zoning Powers of a Planning Board. The planning board shall have all powers heretofore granted by law to the zoning commission of a municipality, and, from and after the creation of a planning board in such municipality, all powers and records of the zoning commission shall be transferred to the planning board; provided, however, that in the event that the existing zoning commission shall be nearing the completion of its zoning plan, council may, by resolution, postpone the said transfer of the zoning commission's powers until the completion of such zoning plan; but such postponement shall not exceed a period of six months. 1935, 55:14

36:12 Authority to Recommend Amendments of Zoning Ordinance. The planning board may, from time to time, recommend to council amendments of the zoning ordinance or zoning map or additions thereto to conform to the board's recommendations for the zoning regulation of the territory comprised within approved subdivision. 1935, 55:15

\section{MASTER PLAN OF THE MUNICIPALITY}

36:13 Purposes of Master P1an. It shall be the function and duty of any planning board established under the provisions of this chapter, to make and to perfect from time to time, so far as funds appropriated by council for such purpose will permit, a master plan for the development of the municipality, including any areas outside of its boundaries which, in the planning board's judgment, bear relation to the planning of the municipality. Such master plan, with the accompanying necessary map, plats, charts and descriptive matter, may be lesigned with the intention of showing as fully as is possible and practical the planning board's recommendations for the desirable development of the territory, legally and logically within the scope of its planning jurisdition, including, on that basis, among other things, the general location, character, and extent of streets, viaducts, subways, tunnels, bridges, waterways, water fronts, boulevards, parkways, roadways in streets and parks, playgrounds, squares, parks, aviation fields, and other public ways, places, grounds, and open spaces, sites for public buildings and other public property, routes of railroads, omnibuses, and other forms of public transportation, and the general location and extent of public utilities and terminals, whether public or privately owned or operated, for water, light, heat, sanitation, transportation, communication, power, and other purposes; also the acceptance, removal, relocation, widening, narrowing, vacating, abandonment, change of use of or extension of any of the foregoing ways, grounds, places, open spaces, buildings, 
36:17 Establishment of Official Map. Provided that the planning board of any municipality shall have adopted a master plan, as provided herein, which includes a major street plan or shall have progressed in its master planning to the stage of the making and adoption of a major street plan, and shall have certified a copy of such major street plan to council, as provided in section 16, council is hereby empowered and authorized to establish an official map of the municipality showing the location of the exterior lines of streets of the whole or of any parts of the municipality theretofore existing laid out and established by law as public streets, and may also show the location of the exterior lines of parks. Such official map is to be deemed to be final and conclusive with respect to the location and width of streets and the location of parks shown thereon. Such official map as may be established pursuant to the terms hereof is hereby declared to be established to conserve and promote the public health, safety, convenience or general welfare. The ordinance establishing or adopting such official map shall provide that a certificate, signed by the city or town clerk, the clerk of the district commissioners, or other duly authorized recording official, giving notice that the said municipality has established an official map, including the date of such establishment, shall forthwith be filed with the register of deeds of the county or counties in which the municipality is situated. Such certificates shall be accompanied by a certified copy of the official map as adopted or established. Whenever a municipality shall have established an official map and shall have filed a certificate to that effect, together with a copy of the said official map, with the register of deed for the county or counties in which the municipality is situated, then no plat of a subdivision of land within said municipality shall thereafter be filed or recorded at the office of the said register of deeds until it shall have been approved by the planning board and such approval entered in writing on the plat by the chairman or secretary of the planning board. 1935, 55:17

36:18 Amendments to Official Map. Council is authorized and empowered, whenever and as often as it may deem it advisable or necessary for the public interest, to change, or add to the official map of the municipality so as to establish the exterior lines of the new streets, or parks, or to widen, extend, relocate, narrow, vacate, abandon, or close existing streets or parks; and the acceptance of, change of use, acquisition of land for, or sale or lease of any street or other public way, ground, place, property, or structure. No change shall become effective until after a public hearing shall have been held in relation thereto, at which parties in interest and citizens shall have had an opportinity to be heard. At least fifteen days' notice of such a public hearing shall be published in a newspaper of general circulation in said municipality and by posting a notice to the same effect at the city or town hall, or in whatever place other notices required by law in connection with municipal affairs are posted o: customarily displayed. Before making such addition, amendment, or change, council shall refer the matter to the planning board for report thereon; but, if the planning board shall not make its report within thirty days of such reference, it shall be deemed thereby to have forfeited the right further to suspend action. In the event that the planning board disapprove the proposed addition, amendment, or change, council shall not have the right to overrule such decision, unless by vote of not less than two thirds of its entire membership in case of a city, or by majority vote of the legal voters present and voting at a regular or special town or district meeting in the case of a town or district. Such additions, amendments, and changes when adopted shall become a part of the official map of the municipality, and shall be deemed to be final and conclusive with respect to the location of the streets and parks shown 
36:20 Recording of Plats. After the certificate or notice referred to in section 19 has been filed with the register of deeds of the county in which the municipality is located, no plat shall be filed or recorded in the offices of the sald register of deeds until it has been approved by the planning board, and such approval has been indorsed in writing on the plat in such manner as the planning board may designate. After such plat is approved and filed, subject, however, to review by court as hereinafter provided, the streets and parks shown on such plat shall be and become a part of the official map of the municipality. The filing or recording of a plat of a subdivision without the approval of the planning board as required hereby shall be void. 1965, 260:2

36:21 Subdivision Regulations; General. Before exercising the powers referred to in section 19 hereof, the planning board shall adopt regulations governing the subdivisions of land within its jurisdiction. Such regulations may provide against such scattered or premature subdivision of land as would involve danger or injury to health, safety, or prosperity by reason of the lack of water supply, drainage, transportation, schools, fire department, or other public services, or necessitate an excessive expenditure of public funds for the supply of such services. Such regulations may provide for the harmonious development of the municipality and its environs; for the proper arrangement and co-ordination of streets within subdivisions in relation to other existing or planned streets or with features of the official map of the municipality; for open spaces of adequate proportions and for suitably located streets of sufficient width to accommodate existing and prospective traffic and to afford adequate light, air, and access of fire-fighting apparatus and equipment to buildings, and be co-ordinated so as to compose a convenient system. The regulations of the board may require in proper cases that plats showing new streets or narrowing or widening thereof submitted to it for approval shall show a park or parks suitably located for playground or other recreational purposes; they may require that proposed parks shall be of reasonable size for neighborhood playgrounds or other recreation uses, and that the land indicated on plats submitted shall be of such character that it can be used for building purposes without danger to health; they may prescribe minimum areas of lots so as to assure conformance with local zoning ordinances and to assure such additional area as may be needed for each lot for on site sanitary facilities and generally may include provisions which will tend to create conditions favorable to health, safety, convenience, or prosperity. 1973, 45:1

\section{$36: 21-a$ Validity.}

I. No subdivision regulation or amendment or exception thereto adopted under RSA 36:21 shall be legal and have any force and effect until copies of such, certified by a majority of the planning board members, are filed with the municipal clerk and the board of selectmen or city council.

II. No purported authority granted by the planning board pursuant to its subdivision regulations shall be legal or have any force and effect unless such regulations have been certified and filed pursuant to paragraph I. $1975,310: 1$

36:22 Additional Requisites. Such regulations of the planning board may stipulate, as a condition precedent to the approval of the plat, the extent to which and the manner in which streets shall be graded and improved and to which 
registered mail, return receipt requested, not less than 5 days before the date fixed for the hearing. The costs of any required publication or posting of notice and the costs of mailing notices of the hearing or placement of a plat on an agenda required under this section shall be paid by the applicant prior to the hearing or consideration. 1979, 323:2

36:24 Status of Plats Approved. Every plat approved by the planning board shall, by virtue of such approval, be deemed to be an amendment of or an addition to or a detail of the official map and a part thereof. Approval of a plat shall not be deemed to constitute or effect an acceptance by the municipality or the public of the dedication of any street or other ground or open space shown upon the plat. 1935, 55:24

$36: 24-\mathrm{a}$ Four-Year Exemption. Every plat approved by the planning board and properly recorded in the registry of deeds shall be exempt from all subsequent changes in subdivision regulations and zoning ordinances adopted by any city or town, except those regulations and ordinances which expressly protect public health standards such as water quality and sewage treatment requirements, for a period of 4 years after the date of recording, provided, however, that once substantial completion of the improvements as shown on the plat have occurred in compliance with the approved plat, or the terms of said approval, the rights of the owner or his successor in interest shall vest and no subsequent changes in subdivision regulations or zoning ordinances shall operate to affect such improvements and further, provided, that:

I. Active and substantial development or building shall have commenced on the site by the owner or his successor in interest in accordance with the approved plat within 12 months after the date of approval, or in accordance with the terms of said approval, and where a bond to cover the costs of roads drains or sewers is required in connection with such approval, such bond is posted with the city or town at the time of commencement of such development.

II. Development remains in full compliance with the public health regulations and ordinances specifled in this section.

III. At the time of approval and recording, the plat conforms to the subdivision regulations and zoning ordinances then in effect at the site of such plat. 1977, 575:1

36:25 Improvements in Unapproved Streets. A municipality which has established and recorded an official map, as provided in section 17 of this chapter, or has conferred upon a planning board platting jurisdiction in accordance with section 19 of this chapter shall not thereafter accept, lay out, open, improve, grade, pave, or light any street or lay or authorize the laying of water mains, sewers, connections, or other facilities or utilities in any street, within any portion of the municipality unless such street (a) shall have been accepted or opened as, or shall otherwise have received the legal status of a public street prior to the conferring of platting jurisdiction upon the planning board, or unless such street (b) corresponds in its location and lines with a street shown on the official map or with a street shown on a subdivision plat approved by the planning board or with a street on a street plat made by and adopted by the board. For the purposes of this section, the word "street" shall not mean or include a discontinued highway. Council may, however, accept, locate and construct any street not shown on 
or sale and may recover the said penalty by civil action. In any such action the prevailing party may recover reasonable court costs and attorneys fees as same may be ordered by the court. 1970, $21: 1$.

36:28 Duties of Register of Deeds. A register of deeds of any county, where plats of subdivisions shall be recorded as provided in RSA $36: 20$, who files or records a plat of a subdivision without the approval of a planning board where required by law shall be guilty of a misdemeanor. 1973, 529:6

36:29 Status of Existing Platting Statutes. From and after the time when a planning board shall expressly have acquired platting jurisdiction in the manner described herein such jurisdiction shall be exclusive and all statutory control over plats or subdivisions of land granted by other statutes shall so far as is in harmony with the provisions hereof be deemed transferred to the planning board as herein authorized and described, and, so far as the regulations of such statutes are inconsistent with such of the powers herein granted as have expressly by ordinance been adopted by a municipality and wherever made available to a planning board according to the provisions hereof, they are hereby declared to have no application, force or effect so long as the said powers conferred hereby shall continue to be exercised by a municipality. 1935, 55:29

\section{REGULATIONS OF BUILDING WITHIN BED OF MAPPED STREETS}

36:30 Refusal of Permit. A municipality which has established and recorded an official map, as provided in section 17 of this chapter, may for the purpose of preserving the integrity of such official map provide by ordinance that from and after the time of such recording no permit shall be issued for any building or structure or part thereof, in the bed of or on any land located between the mapped lines of any street as shown or laid out on such official map except as provided in the following subdivision: 1935, 55:30

\section{APPEALS AND COURT REVIEW}

36:31 Appeals: Where There is a Zoning Ordinance. Any ordinance adopted pursuant to the provisions of section 30 of this chapter shall provide that the board of adjustment created under a local zoning ordinance in accordance with the provisions of chapter 31 and having the power to make variances or exceptions in zoning regulations shall have the further power, in specific cases and by vote of a majority of its members, upon an appeal filed with it by the owner of any such land, to grant a permit based on considerations of justice and equity for a building or structure or part thereof, in such mapped-street location in any case in which such board of adjustment finds, upon the evidence and arguments presented to it upon such appeal, (a) that the property of the appellant of which such mapped-street location forms a part will not yield a reasonable return to the owner unless such permit be granted, or (b) that, balancing the interest of the municipality in preserving the integrity of the official map and in not increasing too greatly the cost of later opening such street, and the interests of the owner in the use and benefits of his property, the grant of such permit is required by considerations of justice and equity. In the event that the said board of adjustment decides to authorize or issue a building permit in such 
CHAPTER 31

New Hampshire Revised Statutes Annotated

ZONING REGULATIONS

31:60 Grant of Power. For the purpose of promoting hea1th, safety, morals, or the general welfare of the community, the legislative body of any cicy or town is empowered to regulate and restrict the height, number of stories and size of buildings and other structures, lot sizes, the percentage of lot that may be occupied, the size of yards, courts and other open spaces, the density of population and the location and use of buildings, structures and 1and for trade, industry, residence or other purposes. 1969, 249:1

31:61 Districts. For any or all of said purposes the local legislative body may divide the municipality into districts of such number, shape and area as may be deemed best suited to carry out the purposes hereof; and within such districts it may regulate and restrict the erection, construction, reconstruction, alteration, repair, or use of buildings, structures, or land. All such regulations shall be uniform for each class or kind of buildings throughout each district, but the regulations in one district may differ from those in other districts. 1925, $92: 2$

31:62 Purposes in View. Such regulations shall be made in accordance with a comprehensive plan and designed to lessen congestion in the streets; to secure safety from fires, panic and other dangers; to promote health and the general welfare; to provide adequate light and air; to prevent the overcrowding of land; to avoid undue concentration of population; to facilitate the adequate provision of transportation, water, sewerage, schools, parks and other public requirements. Such regulations shall be made with reasonable consideretion, among other things, to the character of the district and its peculiar suitability for particular uses, and with a view to conserving the value of buildings and encouraging the most appropriate use of land throughout such municipality. A regulation made under this subdivision shall not apply to existing structures nor to the existing use of any building, but it shall apply to any alteration of a building for use for a purpose or in a manner substantially different from the use to which it was put before alteration. Structures used or to be used by a public utility may be exempted from the operation of any regulation made under this subdivision, if upon petition of such utility the public utilities commission shall after a public hearing decide that the present or proposed situation of the structure in question is reasonably necessary for the convenience or welfare of the public. 1951, 203:2

31:62-a Growth Management; Timing of Development. The legislative body of a city or town may further exercise the poivers granted under this subdivision to regulate and control the timing of development. Any ordinance imposing such a control may be adopted only after preparation and adoption by the planning board of a master plan and capital improvement program and shall be based upon a growth management process intended to assess and balance community development needs and consider regional development needs. 
be submitted to the voters of a town or village district in the following manner: There shall be at least two public hearings at least fifteen days apart on the regulation or restriction at which parties in interest and citizens shal1 have an opportunity to be heard. At least fourteen days' notice of the time and place of each such public hearing shall be published in a paper of general circulation in the town or village district and a legal notice thereof shall also be posted in at least two public places in such town or village district. The public hearings shall be held by the zoning commission or the planning board. After the first public hearing, the zoning commission or the planning board shall consider all changes proposed to the ordinance or amendment at that hearing, and shall vote to accept or reject such changes prior to the second public hearing. The notice of the second public hearing must include either the text or an adequate statement of all changes in the proposed ordinance or amendment considered at the first hearing which were subsequently accepted by the zoning commission or the planning board. At least fourteen days' notice of the time and place of each such public hearing shall be published in a paper of general circulation in the town or village district and a notice thereof shall also be posted in at least two public places in such town or village district. The fourteen days' notice prior to the aforesaid public hearings shall not include the day of posting or publication or the day of the hearing, but shall include any Saturdays, Sundays or legal holidays within the said period. After the second public hearing the zoning commission or the planning board shall, by vote, determine the final form of the ordinance, amendment or amendments, to be presented to the town or village district which shall conform, in substance, to that submitted to the second hearing but may include editorial revisions and textual modifications resulting from the proceedings of that hearing. Official copies of the final proposed ordinance, amendment or amendments, to an existing ordinance and of any proposed zoning map, shall be placed upon file, and shall be made available to the public, at the office of the town or village district clerk four weeks prior to the date at which action is to be taken, and a like copy of the proposed ordinance or amendment to an existing ordinance, and of any proposed zoning map, shall be on display to the voters on the day or the meeting. If the town or village district has adopted an official ballot for the election of its respective officers, the issue as to the adoption of the proposed ordinance or amendment shall be presented to the voters of the town or village district by the inclusion of the following question on the said official ballot as prepared by the town or village district clerk: "Are you in favor of the adoption of the zoning ordinance, (or amendment to the existing town (village district) zoning ordinance) as proposed by the planning board (zoning commission)?" In the event that there shall be more than a single proposed amendment to be submitted to the voters at any given meeting, the issue as to the several amendments shall be put in the following manner: "Are you in favor of the adoption of Amendment No.......as proposed by the planning board (the zoning commission) for the town (village district) zoning ordinance as follcws?" (Here insert topical description of substance of amendment.) If such action is to be taken at a meeting other than the one at which officers are to be elected the clerk shall prepare a special ballot con.taining the question or questions above stated and the meeting shall open not later than noon and shall remain open at least eight hours. If such action is to be taken at a meeting in a town or village district which has not adopted an official ballot the clerk shall likewise prepare a special ballot for the use of voters in voting on the question. If a majority of the voters present and voting on any question or questions as herein provided shall vote 
31:65 Zoning Commission. Such legislative body shall appoint a zoning commission, to recommend the boundaries of the various original districts and appropriate regulations to be enforced therein. Such commission shall make a preliminary report and hold public hearings thereon before submitting its final report, and such legislative body shall not hold its public hearings or take action until it has received the final report of such commission. 1925, 92:6

31:66 Board of Adjustment. Such local legislative body shall provide for the appointment of a board of adjustment 1/, and in regulations and restrictions adopted pursuant to the authority hereof shall provide that the said board may, in appropriate cases and subject to appropriate conditions and safeguards, make special exceptions to the terms of the ordinance in harmony with its general purpose and intent and in accordance with general or specific rules therein contained. 1925, 92:7

31:67 Members of Board; Term, Vacancies. The board of adjustment shall consist of five members. When the board is first organized, one member shall be appointed to serve for one year, one for two years, one for three years, one for four years, and one for five years, and thereafter the appointing authority shall annually appoint one member for a term of five years. Said members shall be removable by the appointing authority upon written charges, and after public hearing. Vacancies shall be filled for the unexpired term. 1933, 36:1

31:67-a Alternates; Term, Vacancies. The board of adjustment of each municipality may also include not more than five alternate members. Whenever a regular member shall be absent, the chairman shall designate an alternate, if an alternate is present, to act in the absent member's place. Said alternate members shall be removable by the appointing authority upon written charges, and after public hearing in the same manner as provided in RSA 31:67. Vacancies among the alternates shall be filled for the unexpired term. 1975, 100:1

31:68 Meetings of Board, etc. The board shall adopt rules in accordance with the provisions of the ordinances. Meetings of the board shall be held at the call of the chairman and at such other times as the board may determine. Such chairman, or in his absence the acting chairman, may administer oaths and compel the attendance of witnesses. All meetings of the board shall be open to the public. The board shall keep minutes of its proceedings, showing the vote of each member upon each question, or, if absent or failing to vote, indicating such fact, and shall keep records of its examinations and other official actions, all of which shall be immediately filed in the office of the board and shall be a public record. 1925, 92:7

31:69 Appeals to Board. Appeals to the board of adjustment may be taken by any person aggrieved or by any officer, department, board, or bureau of the municipality affected by any deciston of the administrative officer. Such appeal shall be taken within a reasonable time, as provided by the rules of the board, by filing with the officer from whom the appeal

1/ Appointment of alternates. The legislative body of each municipality which has a board of adjustment may provide for the appointment of alternates as provided in RSA 31:67-a. 1973, 505:2 
end shall have all the powers of the officer from whom the appeal is taken.

$v$. The concurring vote of three members of the board shall be necessary to reverse any action of such administrative official, or to decide in favor of the applicant on any matter upon which it is required to pass under any such ordinance, or to effect any variation in such ordinance. 1941, 2:1

31:73 Disqualification of Board Member. No member of the board of adjustment shall sit upon the hearing of any question which the board is to decide in judicial capacity who would be disqualified from any cause, except exemption from service and knowledge of the facts involved gained in the performance of his official duties, to act as a juror upon the trail of the same matter in any action at law. If a member shall be disqualified or unable to act in any particular case pending before the board the appointing authority, upon application of the board, shall appoint a member to act in his place upon said case. $1933,36: 2$

31:74 Motion for Rehearing. Within 20 days after any order or decision of the board of adjustment, or any decision of the legislative body of such municipality in regard to its plan of zoning, the selectmen, any party to the action or proceedings, or any person directly affected thereby, may apply for a rehearing in respect to any matter determined in the action or proceeding, or covered or included in the order, specifying the motion for rehearing the ground therefor, and the board of adjustment, or the legislative body of such municipality, may grant such rehearing if in its opinion good reason therefor is stated in said motion. If the decision complained against is that made by a town meeting, the application for rehearing shall be made to the board of selectmenand upon recelpt of such application, the board of selectmen shall hold a rehearing within 30 days after receipt of the petition. Following the rehearing if in the judgement of the selectmen the protest warrants action, the selectmen shall call a special tow meeting. 1977, 226:1

31:75 Specifications. Such motion shall set forth fully every ground upon which it is claimed that the decision or order complained of is unlawful or unreasonable. No appeal from any order or decision of the board of adjustment or legislative body of such municipality shall be taken unless the appellant shall have made application for rehearing as herein provided, and when such application shall have been made, no ground not set forth therein shall be urged, relied on, or given any consideration by the court, unless the court for good cause shown shall allow the appellant to specify additional grounds. $1949,278: 1$

31:76 Action on Motion. Upon the filing of such motion for rehearing the board of adjustment or the legislative body of a city shall within ten days either grant or deny the same, or suspend the order or decision complained of pending further consideration and any order of suspension may be upon such terms and conditions as the board of adjustment or legislative body of a city may prescribe. In case the motion for rehearing is against a decision of the legislative body of a town and if the selectmen, as provided in section 74 , shall have called a special town meeting within twenty-five days from the receipt of application for such rehearing, the town shall grant or deny the same or suspend the order or decision complained of pending further consideration and any order of suspension may be upon such terms and conditions as the town nay prescribe. $1949,278: 2$ 


\section{APPENDIX C}

MODEL PLANNING BOARD BY-LAWS

BY-LAWS

PLANNING BOARD

TOWN OF

, New Hampshire

Article I

Article II

Article II

Article IV
NAME. The name of the Board shall be " Planning Board" as adopted at the Town Meeting on , 19 .

PERSONNEL. The Planning Board shall consist of members, appointed by the Board of selectmen, and shall include one selectmen, to act as an ex officio member, with power to vote.

Selection, qualifications, terms removal of members, and filling of vacancies shall conform with sections 4 through 7 inclusive, Chapter 36, New Hampshire Revised Statutes Annotated, 1955, as amended.

ORGANIZATION. The Planning Board shall meet each year within 30 days of the annual town meeting for the purpose of electing one of its members as chairman; one of its members as vice-chairman; one of its members as treasurer. If requested by a majority of those present, voting shall be by ballot.

OFFICERS.

A. The chairman shall call the meeting to order, preside over the deliberations, and see that all proceedings are held in accordance with the Rules of the Town of, and the Laws of the State of New Hampshire. He shall prepare, with the assistance of the secretary, an annual report, appoint committees of resident citizens including one member of the Planning Board who shall act as chairman, and perform other duties customary to the office. In the absence of the chairman, the vicechairman shall preside. 
B. The Secretary shall keep a full and accurate record of the proceedings of each meeting. He shall issue notices of all meetings; record the names of members present; and notify all committees of their appointment. He shall notify applicants and abutters of hearings required by law (i.e. subdivision or site plan review). He shall prepare such correspondence and fulfill such duties as the chairman may specify. In the absence of the secretary, the chairor vice-chairman shall be responsible for the records of the meeting.

C. The treasurer shall receive all funds of the Planning Board; issue receipts for the same; and see that such funds are properly recorded on the Town books. He shall present an itemized accounting of receipts and expenditures at each regular meeting.

Article $V$ MEETINGS.

A. Regular meetings shall be held at least monthly, the date, time and place to be selected by majority vote of the Board, taken at the annual organizational meeting.

B. Special meetings may be called by the chairman, or in his absence, by the vice-chairman, at the request of three members of the Planning Board. Notice shall be given at least 48 hours in advance of such meetings. The chairman, or in his absence, the vice-chairman, shall select the time, date and place of the meeting. No business shall be acted upon at a special meeting unless members are present.

C. A regular meeting may be postponed by the chairman if requested by three voting members and all members are so notified. At least one regular meeting must be held every three months in accordance with section 8, chapter 36, N.H. Revised Statutes Annotated, 1955.

D. voting members shall constitute a quorum for the transaction of business, but a lesser number may meet and adjourn.

E. The order of business at regular meetings shall be as follows:

1. Call to order by chairman

2. Roll call by the secretary

3. Minutes of previous meeting

4. Reading of communications directed to the Board

5. Reports of committees 


\begin{abstract}
6. Treasurer's report
7. Unfinished business

8. Hearings on subdivisions and

site plans

9. Other business (citizen matters)

10. Adjournment

F. A motion, duly seconded, shall be carried by a majority of members present voting in the affirmative.

G. Any rules and regulations may be suspended at any meeting, or for a shorter time by vote of two thirds of the members present.
\end{abstract}

Article VI PUBLIC HEARINGS - SUBDIVISIONS AND SITE PLANS The conduct of public hearings on preliminary and final plats of subdivisions and site plans shall be governed by the following rules:

A. The chairman shall open the hearing and report on the manner in which personal notice was given.

B. Applicant shall be called to present his proposal.

C. Those speaking in favor or in opposition to the proposal shall be allowed to speak.

D. All questions on the proposal shall be directed to the chairman.

Article VII APPLICATIONS. Applications for subdivision and site plan review shall be made on forms provided by the Board and shall be presented to the secretary of the Planning Board.

At each meeting, the secretary shall present to the Board all applications received by him prior to the beginning of the meeting.

All applicants shall be invited to meet with the Planning Board at its next regular scheduled meeting to discuss the proposal.

Article VIII FORMS. All forms prescribed herein and revisions thereof shall be adopted by resolution of the Board and shall become a part of these By-Laws.

Article IX PERSONAL NOTICE. Personal notice of public hearings on each application shall be made by certified mail, return receipt requested, to the applicant and all abutters to the applicant's property. An abutter is defined in accordance with the provisions of section I-IX of chapter 36, N.H. Revised 
Statutes Annotated, 1955. Notice shall also be given to other parties deemed by the Board to have special interest. Said notice shall contain the name of the applicant, description of the property, action desired by the applicant, the date, time, and place of the meeting.

Article $\mathrm{X}$ AMENDMENTS. These By-Laws may be amended by a majority vote of the members of the Board provided that such amendment is read at two successive meetings immediately preceding the meeting at which the vote is to be taken.

SOURCE: Southern New Hampshire Planning Commission, Handbook For Planning Boards And Boards of Adjustment, 1973. 


\section{APPENDIX D}

\section{ORGANIZATION OF THE ZONING ORDINANCE}

100. Title and Purpose - Officially states the title and purpose of the ordinance.

200. Definitions - Explains terms used in the ordinance.

300. Application of Regulations - States the conditions under which the ordinance must be applied.

400. Zoning District Regulations - Specifies the detailed regulations to be applied to each district.

500. Supplementary Regulations - Summarizes additional regulations applied to all districts; and, regulations related to parking, loading space, signs and non-conforming uses.

600. Board of Adjustment - Explains the powers and duties of the Board of Adjustment; and, explains the board's procedures in making special exceptions or variances.

700. Administration And Enforcement - specifies who shall be responsible for administering and enforcing the zoning ordinance and what permits must be secured prior to the start of building construction. This section also includes fees and procedures for amending the zoning ordinance.

SOURCE: Southern New Hampshire Planning Commission, Handbook For Planning Boards And Boards of Adjustment, 1973, p. $4-\overline{5}$. 


\section{APPENDIX E}

\section{ADOPTION PROCEDURE FOR ZONING ORDINANCE}

VILLAGES AND TOWNS

Planning Board prepares

proposed Zoning ordinance

Publish and Post Notice of first Hearing

14 days

(16 days to

be safe)

lst Hearing

Make any changes in proposed zoning ordinance

Publish and Post Notice of 2nd (Last) Hearing

\section{4 days \\ (16 days to \\ be safe)}

2nd Hearing

Planning Board reviews

Zoning Ordinance
Planning Board drafts a proposed Zoning ordinance.

Notice of hearing published in one newspaper having general circulation in town and posted in three public places in town. Notice of hearing includes purpose, time, place and date of hearing. Also should include where copies of ordinance including map may be obtained or inspected.

At least 14 days after publication and posting not including day of publication and day of hearing.

Planning Board holds hearing.

Planning Board considers all changes proposed at hearing and decides which proposed changes to incorporate.

Notice of hearing same as for 1st hearing, except that notice of 2 nd hearing includes text or an adequate statement of all changes in the proposed ordinance.

At least 14 days after publication and posting not including day of publication and day of hearing.

Planning Board holds hearing.

Planning Board votes on the final form of the ordinance. Must conform in substance to that submitted to the second hearing, but may include editorial revisions and textual modifications as a result of the hearing. Planning Board requests selectmen to place article 
Selectmen Prepare and Post Warrant

14 days

(16 days to be safe)

Town Meeting in warrant or call special town meeting to act on the proposed Zoning ordinance. Zoning ordinance placed on file at Town Clerk's office for public inspection.

Selectmen prepare a warrant (RSA 39) giving place and date of town meeting, containing an article to vote on Zoning ordinance. Post warrant at place of meeting and one other public place.

At least 14 days after posting not including day of posting and meeting hold town meeting.

Vote to adopt or reject proposed Zoning ordinance.

1. If town has official ballot for the election of officers, the vote for zoning shall be by official or special ballot as follows: "Are you in favor of the adoption of the zoning ordinance as proposed by the Planning Board?" The polls shall be open for at least 8 hours for voting (RSA 31:63-a).

2. In other towns the Town Clerk shall prepare a special ballot worded as above for voting at town meeting (RSA 31:63-a).

3. I f the amendment to the zoning ordinance is by petition the following question shall be submitted to the voters: "Are you in favor of the adoption of the amendment to the zoning ordinance as proposed by petition of the voters for this town (village district)?" The manner of voting for this shall be as prescribed in section 63-a (RSA 31:63-b).

For detailed procedure in calling and conducting a town meeting refer to The New Hampshire Town Meeting Handbook, published by the New Hampshire Municipal Association.

SOURCE: N.H. Office of State Planning, Growth Management Volume I (Concord, N.H.: Office of state Planning, 1977). 


\section{APPENDIX F}

Criteria For Subdivision Site Impact Analysis

FACTOR

A. Schools

\section{INFORMATION REQUIRED POSSIBLE CRITERIA}

1. Existing enrollments 1. New students would

2. Design capacity of schools.

3. Teacher/student ratios

4. Projected school-age children from development. exceed capacity of school.

2. New students would require additional teachers and/or affect Teacher/student ratio.

B. Vehicular Access 1. Condition and capac- 1. ity of access roads and intersections.

2. Existing traffic volumes.

Access roads or intersections would need improvement.

2. Development is remote from arterial.

3. Distance to arterial 3. Year-round access

4. Availability of public transportation. adequate for emergency vehicles.

5. Hazardous or season- 4. Is multiple access ally impassable conditions. necessary for emergencies.

6. Projected traffic volume from development.

C. Water Supply

1. Development served by public, private

1. Development would or community system.

2. Public system, require extension or increase in size of main.

a) Distance to water main.

b) Size of main.

c) Capacity of supply

2. Development would require improvements to other water supply components.

3. Private or Community.

a) Groundwater favorability.

\section{Sanitary sewage}

1. Development served 1 by public, individual or community system.

2. Public system,

- Development would re-

a) Distance to sewage line,

b) Size of line,

c) Capacity of treatment facilities. quire extension or increase in size of line.

2. Development would require improvements in treatment facilities.

3. Private disposal would threaten potable water supplies.

3. Individual or Community
a) WSPCC results,
b) Soils analysis,
c) Distance to surface waters, wells or aquifers. 
FACTOR

E. Drainage
INFORMATION REQUIRED

1. Percent of area impervious to runoff.

2. Proposed facilities to handle runoff (storm drains, culverts, retention ponds, etc.)
POSSIBLE CRITERIA

1. Development would create downstream runoff problems.

2 . Drainage would affect individual wells or septic systems.

\section{F. Fire Protection}

1. Distance to fire station

2. Distance to fire hydrants,

a) Pressure and capacity of hydrant system.

3. Distance to surface waters

or dry wells.

These criteria may have to be amended to meet the needs of individual communities.

SOURCE: Planning And Development Techniques: Options For Managing Community Growth in New Hampshire, New Hampshire office of state Planning, 1979. 


\section{APPENDIX G}

Suggested Organization of Subdivision Regulations

100 INTRODUCTION - Includes: Authority, Title, Purpose, Jurisdiction, and Definitions.

200 GENRAL PROVISIONS - Requires review and approval prior to any work within subdivision.

300 PROCEDURE PRIOR TO PREPARATION AND SUBMISSION OR PRELIMINARY PLAN - Self explanatory.

400 PRELIMINARY PLAN: PROCEDURE AND INFORMATION REQUIRED ON PLAN Describes drawing requirements; provides for site inspection; cites provision for other studies if necessary; and outlines procedure for obtaining conditional approval.

500 GENERAL REQUIREMENTS AND DESIGN STANDARDS FOR SUBDIVISION PLAN Describes general and specific requirements governing design of the subdivision, including streets, blocks, lots, monuments, etc.

600 THE FINAL PLAN: CONTESTS, FILING AND RECORDING PROCEDURE Details requirements for graphic presentation; posting of performance bond; procedure for review and approval; and recording requirement.

700 RELEASE OF PERFORMANCE BOND - Self explanatory.

800 ADMINISTRATIVE PROVISIONS - Defines planning board responsibilities; provides penalty for illegal sale or transfer of lots; and establishes conditions for issuance of building permits and acceptance of new streets.

900 LEGAL PROVISIONS - Establishes effective date of regulations; repeals conflicting regulations; includes provision for rehearing; and clarifies severability.

SOURCE: Handbook For Planning Board And Boards of Adjustment, Southern New Hampshire Regional Planning Commission, 1973. 


\section{APPENDIX H}

SITE PLAN REVIEW CHECKLIST

SALEM, N.H. PLANNING BOARD

\section{INTRODUCTION}

The purpose of this checklist is to expedite the review process for the Planning Board and applicant. It is intended as a guide. All Site Development $\mathrm{Plans}$ shall conform to applicable requirements of the Salem zoning ordinance, Subdivision Regulations, and other applicable Local, state, and Federal regulations.

PLAN FORMAT REQUIREMENTS

1. Title Block: Refer to Exhibit $A$ for required title block format.

2. Location plan and north arrow showing relevant streets and zoning district boundaries.

3. Names and addresses of all owners of record of abutting parcels.

EXISTING BUILDINGS, UTILITIES AND DRAINAGE

4. Location of existing buildings, existing water, sewer, culverts, and drainage ditches on property showing pipe sizes, grades and direction of flow; and existing utility lines, poles, outdoor lighting, gaslines, LP tanks, oil and fuel tanks, and holding tanks.

5. Location of existing water, sewer, culverts, drainage ditches, fire hydrants and sidewalks that are within five hundred (500') feet of the subject parcel, or such facilities which will be utilized by the site development.

6. Location of existing easement(s) or right(s) of way(s).

\section{TOPOGRAPHIC DATA}

7. Existing and proposed spot elevations and contours at two ( $2^{\prime}$ ) foot intervals, referred to USGS benchmarks if recoverable within one and one-half $\left(1 \frac{1}{2}\right)$ miles, and definition of property boundaries.

8. Location of existing landmarks including streams, brooks, wetlands, flood plains as shown on Salem New Hampshire Flood Plain Map, rock out-crops, wooded areas, isolated trees with a diameter of eight ( $8^{\prime \prime}$ ) inches or more, measured three $\left(3^{\prime}\right)$ feet above the trunk; and other such significant existing environmental features.

9. Identify soil types, stating source of information. 


\section{SITE DEVELOPMENT DATA}

10. Proposed location of buildings) and dimensions of building(s) in square feet (including basement area); and proposed loading and unloading areas (screened from public areas and/or adjacent property where necessary); and corner grades, floor elevations of proposed building(s), front elevation, and an artist's rendering of the proposed building(s).

11. Distances on all sides between proposed building(s) and property lines.

12. Proposed fire lanes. Site layout shall be designed to provide for appropriate access to all buildings by fire apparatus, consistent with recognized good practice for the safe guarding to a reasonable degree of life and property from the hazards of fire. Location and width of fire lanes shall be subject to the requirements of the Salem, NH Fire Lane Policy of 1974, and any subsequent amendments, and approved by the Fire Inspector.

13. Pedestrian sidewalks adjacent to building and on site.

14. Proposed streets and sidewalks (sidewalks required if there are existing sidewalks within one thousand $\left(1,000^{\prime}\right)$ feet, accompanied with a road profile.

15. Proposed means of vehicular access and egress to and from the site onto public streets with curb cut widths and radil. Off-street Parking (refer to off-street Parking Requirements of Article IX of the Salem, New Hampshire zoning ordinance).

16. Location of proposed fire hydrants, utility poles and lines, water, sewer, well, septic tank systems, gaslines and LP tanks. Show grade and invert elevations for sewer, water, and storm drain pipes, and locate catch basins sewer manholes and watergate valves.

17. Proposed outdoor lighting that conforms to the New Hampshire Energy Code (RSA 155-D) which permits a maximum of .10 watts per linear foot for parking lot lighting, and 5.00 watts per linear foot for wall wash, facade, or canopy.

18. Proposed planting and landscaping with specific locations, sizes, species and quantities; proposed buffer zones (one hundred feet being required between industrial and residentially zoned land in the Industrial District), screening and fencing; and refuse are to be screened. 
19. Possible sources of noise which may be at a decibel level that would create a nuisance for a residential neighborhood.

20. Sign application review sheet (if applicant seeks simultaneous approval of signage). Proposed signage subject to the size, number permitted, and setback requirements of the Salem, New Hamphire Sign ordinance.

21. Dredge and fill permit required: ( ) YES ( ) NO

This checklist is intended to expedite the work of the Municipal Staff, Planning Board, and the applicant. It is not intended as a substitute for, nor does it contain all of the information and requirements in the zoning ordinance and other applicable Municipal codes, ordinances, and procedures.

SOURCE: Town of Salem, N.H. Planning Board site Plan Review Regulations, 1981. 


\section{APPENDIX I}

\section{GLOSSARY OF PLANNING TERMS}

Base Map - A map showing the important natural and man-made features of a community. Such maps are used to establish consistency when maps are used for various purposes, i.e. Showing natural resource limitations, public facilities, land use and zoning districts.

Board of Adjustment - A local body, created by ordinancy (RSA 31:65), whose responsibility is to hear appeals from decisions of the local zoning administrator and to consider requests for variances and exceptions permissible under the terms of the New Hampshire zoning legislation and the local zoning ordinance.

Building coverage - The amount of land covered or permitted to be covered by a building, usually measured in terms of percentage of a lot.

Captial Improvements Program - A financial management tool for scheduling and budgeting future public improvements required to service both existing and future development with consideration of priorities and the financial capabilities of the community.

Cluster Development - A clustering of housing units on a single tract of land with the remaining land designated as open space which is in contrast to the conventional gridiron pattern of development where the housing units are spread evenly throughout the tract of land with no remaining open space.

Dedication - Under subdivision regulations, the transfer of property from private to public ownership. Subdivision regulations have traditionally required developers to build streets and utility lines to municipal specifications and then dedicate them to the public.

Easement - A right given by the owner of land to another party for specific limited use of that land, i.e. drainage easement.

Exclusionary Zoning - Zoning which has the effect of keeping out of a community racial minorities, poor people, or additional population of any kind.

Floodplain - Land area adjoining a stream, river, ocean, lake or other body of water which may reasonably be expected to be covered at some time by floodwater.

Growth Management - A system of government regulation and financial action, founded by statutory requirements and constitutional protection of private property rights which, insures that the rate, density and location of the use of land does not exceed the capacity of the natural and man-made environment to the extent that it threatens the health, safety or general welfare of the community. 
Mixed-Use Zoning - Zoning that permits a combination of usually separated uses within a single development.

Moratorium - A temporary halting or severe restriction of development activity.

Phased Development Control - A term referring to programs or techniques to guide the timing and sequencing of development.

Planned Unit Development - A land development project comprehensively planned as a unified site design which permits flexibility in building siting, mixture of residential, open space, commercial and/or industrial land uses, and the preservation of significant natural features.

Police Power - The authority of government to exercise controls to protect public health, safety, morals and general welfare (RSA 31:39).

Policy - A statement or document of a public body that forms the basis for enacting legislation or making decisions.

Site Plan - A plan to scale, showing use and structures proposed for a parcel of land as required by local regulations (RSA 36:19-a).

spot zoning - zoning a relatively small area differently from the zoning of the surrounding area, usually for an incompatible use and to favor the owner of a particular piece(s) of property.

Variance - A device that grants a property owner relief from certain provisions of a zoning ordinance when, because of the particular physical surroundings, shape or topographical conditions of the property, compliance would result in a particular hardship upon the owner, as distinguished from a mere inconvenience or a desire to make money.

Zoning - A police power measure, enacted by local governments, in which the community is divided into districts or zones within which permitted and special uses are established as are regulations governing lot sizes, building bulk, placement and other development standards. Requirements may vary from district to district, but must be uniform within districts. 